\title{
Molecular Characterization of the Ankle-Link Complex in Cochlear Hair Cells and Its Role in the Hair Bundle Functioning
}

\author{
Nicolas Michalski, ${ }^{1 \star}$ Vincent Michel, ${ }^{1 \star}$ Amel Bahloul, ${ }^{1}$ Gaëlle Lefèvre,,${ }^{1}$ Jérémie Barral, ${ }^{3}$ Hideshi Yagi, ${ }^{2}$ \\ Sébastien Chardenoux, ${ }^{1}$ Dominique Weil, ${ }^{1}$ Pascal Martin, ${ }^{3}$ Jean-Pierre Hardelin, ${ }^{1}$ Makoto Sato, ${ }^{2}$ and Christine Petit ${ }^{1}$ \\ ${ }^{1}$ Institut National de la Santé et de la Recherche Médicale Unité Mixte de Recherche en Santé 587, Collège de France, Institut Pasteur, 75724 Paris cedex 15 , \\ France, ${ }^{2}$ Division of Cell Biology and Neuroscience, Department of Morphological and Physiological Sciences, Research and Education Program for Life \\ Science, University of Fukui, Eiheiji, Fukui 910-1193, Japan, and ${ }^{3}$ Centre National de la Recherche Scientifique Unité Mixte de Recherche 168, Institut Curie, \\ 75248 Paris cedex 05, France
}

Several lines of evidence indicate that very large G-protein-coupled receptor 1 (Vlgr1) makes up the ankle links that connect the stereocilia of hair cells at their base. Here, we show that the transmembrane protein usherin, the putative transmembrane protein vezatin, and the PDZ (postsynaptic density-95/Discs large/zona occludens-1) domain-containing submembrane protein whirlin are colocalized with Vlgr1 at the stereocilia base in developing cochlear hair cells and are absent in $V \operatorname{lgr} 1^{-/-}$mice that lack the ankle links. Direct in vitro interactions between these four proteins further support their involvement in a molecular complex associated with the ankle links and scaffolded by whirlin. In addition, the delocalization of these proteins in myosin VIIa defective mutant mice as well as the myosin VIIa tail direct interactions with vezatin, whirlin, and, we show, Vlgrl and usherin, suggest that myosin VIIa conveys proteins of the ankle-link complex to the stereocilia. Adenylyl cyclase 6, which was found at the base of stereocilia, was both overexpressed and mislocated in $\mathrm{VlgrI}^{-1-}$ mice. In postnatal day $7 \mathrm{VlgrI}^{-1-}$ mice, mechanoelectrical transduction currents evoked by displacements of the hair bundle toward the tallest stereocilia (i.e., in the excitatory direction) were reduced in outer but not inner hair cells. In both cell types, stimulation of the hair bundle in the opposite direction paradoxically resulted in significant transduction currents. The absence of ankle-linkmediated cohesive forces within hair bundles lacking Vlgr 1 may account for the electrophysiological results. However, because some long cadherin-23 isoforms could no longer be detected in $\mathrm{Vlgr}^{-/-}$mice shortly after birth, the loss of some apical links could be involved too. The premature disappearance of these cadherin isoforms in the $\mathrm{Vlgrl}^{-1-}$ mutant argues in favor of a signaling function of the ankle links in hair bundle differentiation.

Key words: cochlea; hair bundle; ankle link; Vlgrl; adenylyl cyclase 6; Usher syndrome

\section{Introduction}

The two types of cochlear sensory cells, the inner hair cells (IHCs), the genuine sensory cells, and the outer hair cells (OHCs), the cochlear amplifiers, transduce sound-evoked mechanical stimuli into electrical signals in the hair bundle. The hair bundle is composed of an array of modified microvilli, the stere-

Received Jan. 25, 2007; revised May 2, 2007; accepted May 10, 2007.

This work was supported by the Fondation Raymonde et Guy Strittmatter, the European Commission FP6 Integrated Project EuroHear LSHG-CT-2004-512063, Ernst-Jung Stiftung für Medizin Preis, and A \& M Suchert-Retina Kontra Blindheit. N.M. was supported by a fellowship from the Ministère de l'Education Nationale, de la Recherche et de la Technologie. We are deeply indebted to R. Fettiplace for teaching hair-cell patch clamping to N.M. and for his suggestions for improving this manuscript. We thank M. Beurg and L. Prado de Carvalho for numerous pieces of advice. We also thank E. Bizard and S. Nouaille for technical help; Y. Yamasaki and G. P. Richardson for providing us with the anti-whirlin and anti-Ptprq antibodies, respectively; J. Levilliers for her help in the preparation of this manuscript; and J. Ashmore for careful reading of this manuscript.

${ }^{*}$ N.M. and V.M. contributed equally to this work.

Correspondence should be addressed to Christine Petit, Institut National de la Santé et de la Recherche Médicale Unité Mixte de Recherche 587, Unité de Génétique des Déficits Sensoriels, Collège de France, Institut Pasteur, 25 rue du Dr Roux, 75724 Paris cedex 15, France. E-mail: cpetit@pasteur.fr.

D0I:10.1523/JNEUROSCI.0342-07.2007

Copyright $\odot 2007$ Society for Neuroscience $\quad$ 0270-6474/07/276478-11\$15.00/0 ocilia, organized in three rows of graded length. During development, it also harbors a genuine cilium, the kinocilium. The architecture, orientation, and stiffness of the hair bundle are critically involved in the mechanoelectrical transduction (MET) process. Strong evidence supports the role of the tip link, a single link extending upward the tip of each stereocilium to the side of the adjacent taller stereocilium, in this process via mechanical coupling to the MET apparatus (Pickles et al., 1984; Assad et al., 1991). The hair bundle also contains multiple lateral links that bridge stereocilia within and across stereocilia rows (Goodyear et al., 2005).

The study of the proteins encoded by genes defective in Usher syndrome type 1 (USH1), characterized by congenital profound deafness, has shown that cadherin 23 (USH1D) and probably protocadherin 15 (USH1F) make up lateral links that interconnect the stereocilia as well as the stereocilia to the kinocilium during hair bundle differentiation (Ahmed et al., 2001; Alagramam et al., 2001; Bolz et al., 2001; Bork et al., 2001; Lagziel et al., 2005; Michel et al., 2005). These links are thought to be critically involved in the cohesion of the growing hair bundle, because in 
mutant mice that lack either cadherin 23 or protocadherin 15 , the hair bundle is fragmented before birth (Holme and Steel, 2002; El-Amraoui and Petit, 2005) (G. Lefèvre, unpublished results). In addition, subgroups of lateral links can be distinguished thereafter. In the postnatal mouse, they are categorized according to their location along stereocilia, namely from base to apex, ankle links, shaft links, and top links. Of these, only the top links persist in the fully mature hair bundle of cochlear hair cells (Goodyear et al., 2005). The roles of the various lateral links remain largely elusive.

The ankle links are present in all vertebrate species, both in the auditory and vestibular hair bundles, although they are only transient in the mammalian cochlear hair cells. Recently usherin and very large G-protein-coupled receptor 1 (Vlgr1), two transmembrane proteins encoded by genes defective in Usher syndrome type 2 (USH2A and $U S H 2 C$, respectively), characterized by a less severe hearing impairment than in USH1, were suggested to be components of the ankle links because they are both located at the base of stereocilia (Adato et al., 2005b; McGee et al., 2006) and have a long extracellular region. Usherin extracellular region is composed of fibronectin type III repeats (up to 33 repeats) and four different types of laminin-like domains (van Wijk et al., 2004). Vlgr1 belongs to the B-subclass of G-protein-coupled receptors (GPCRs), which gathers proteins with unusually large N-terminal extracellular domains (McMillan et al., 2002; Foord et al., 2005). Its large extracellular region mostly consists of 35 copies of $\sim 120$ aa Calx- $\beta$ domains. The disappearance of the ankle links in Vlgrldel7TM mutant mice further suggests that Vlgrl is an ankle-link component (McGee et al., 2006). Here, we addressed the molecular composition and role of the ankle links in the hair bundle development and functioning.

\section{Materials and Methods}

Animals and antibodies. Animal experiments were performed in accordance with the Institut de la Santé et de la Recherche Médicale animal welfare guidelines, approved by the French Ministère de l'Agriculture, de l'Alimentation, de la Pêche et de la Ruralité. The $V \operatorname{lgr} 1^{-/-}$mice have been reported previously (Yagi et al., 2005). Rabbit antisera were raised against a synthetic peptide, VLRGKDSDGN, from the N-terminal region of the murine Vlgr1 protein [National Center for Biotechnology Information (NCBI) accession number NM_054053, amino acids 282-291]. Polyclonal antibodies were then affinity purified. Other primary antibodies used in this study were as follows: rabbit anti-mouse usherin (Adato et al., 2005b), rabbit anti-mouse Cdh23N1, rabbit anti-mouse Cdh23Ela3N (Michel et al., 2005), rabbit anti-mouse Ptprq (gift from G. P. Richardson, University of Sussex, Brighton, UK), mouse anti-mouse CIP98/ whirlin (Yap et al., 2003; Delprat et al., 2005), rabbit anti-mouse AC5/6 (Santa Cruz Biotechnology, Santa Cruz, CA), and rabbit anti-mouse vezatin (Boëda et al., 2002). Secondary antibodies were: Alexa 488conjugated goat anti-rabbit Fab2 (Invitrogen, Eugene, OR), cyanine 3 (Cy3)-conjugated goat anti-mouse, and Cy5-conjugated goat anti-rabbit (GE Healthcare, Piscataway, NJ).

Whole-mount fluorescence. Animals at different developmental stages were killed by exposure to $\mathrm{CO}_{2}$ followed by decapitation, and cochleas were dissected from temporal bones. The cochlear shells were removed and placed in PBS. The organ of Corti was exposed by removing the cochlear lateral wall, and the tissues were then fixed in 4\% paraformaldehyde PBS for $1 \mathrm{~h}$ at room temperature. The tissues were washed three times in PBS (10 min for each wash), followed by permeabilization and blocking in PBS containing $1 \%$ bovine serum albumin (BSA), 20\% normal goat serum, and $0.3 \%$ Triton $\mathrm{X}-100$ for $1 \mathrm{~h}$ at room temperature. After PBS washes, primary antibodies, diluted in PBS containing 1\% BSA and $0.25 \%$ Triton X-100, were incubated overnight at $4^{\circ} \mathrm{C}$. Omission of the primary antibody was used as a negative control. After three $10 \mathrm{~min}$ washes in PBS, the tissues were incubated with secondary antibodies diluted in 1\% BSA-PBS containing TRITC-conjugated or Alexa 488- conjugated phalloidin (1:2000 dilution) for $1 \mathrm{~h}$ at room temperature. After three washes in PBS, the tectorial membrane was carefully dissected away and the organs of Corti were mounted in Fluorsave (Calbiochem, La Jolla, CA), under glass coverslips with the hair bundles directed toward the coverslip. Whole-mount preparations were viewed with a $63 \times$ Plan Apochromat oil-immersion objective (numerical aperture, 1.2) using a Zeiss (Oberkochen, Germany) LSM-510 confocal microscope.

For double-labeling experiments using two rabbit primary antibodies (supplemental Fig. 1, available at www.jneurosci.org as supplemental material), the following modifications were done to the above protocol. The fixed tissue samples were sequentially incubated with the primary antibody (anti-Vlgr1) and a Cy5-conjugated secondary antibody (1:500 dilution) for 1.5 and $1 \mathrm{~h}$ at room temperature, respectively. Tissue samples were fixed again in $4 \%$ paraformaldehyde PBS for $15 \mathrm{~min}$ at room temperature. They were then sequentially incubated with the second primary antibody (anti-usherin or anti-vezatin) overnight at $4^{\circ} \mathrm{C}$ and an Alexa 488-conjugated secondary antibody (1:800 dilution) for $15 \mathrm{~min}$ at room temperature, followed by a 15 min fixation in $4 \%$ paraformaldehyde PBS. Finally, tissue samples were incubated with Cy3-conjugated phalloidin (1:2000 dilution). Omission of the second primary antibody (anti-usherin or anti-vezatin) was used as a negative control.

BAPTA and subtilisin treatments. After dissection (see above), organs of Corti were placed in microwells and incubated with either PBS, PBS containing $5 \mathrm{~mm}$ BAPTA, or PBS containing $50 \mu \mathrm{g} / \mathrm{ml}$ subtilisin [Sigma (St. Louis, MO) Protease type XXIV] for $15 \mathrm{~min}$ at room temperature. After treatment with PBS, BAPTA, or subtilisin, the solutions were removed, and fixative (4\% paraformaldehyde in PBS) was added. After fixation for $1 \mathrm{~h}$ at room temperature, the organs of Corti were immunolabeled as described above.

Scanning electron microscopy. Whole inner ears from postnatal day 6 (P6) $\mathrm{Vlgrl}^{+/+}, \mathrm{Vlgrl}^{+/-}$, and $\mathrm{Vlgr} \mathrm{I}^{-/-}$mice were removed, pierced at the apex of the cochlea and in the round and oval windows, and fixed by immersion in $2.5 \%$ glutaraldehyde in $0.1 \mathrm{M}$ phosphate buffer, $\mathrm{pH} 7.3$, for $2 \mathrm{~h}$ at room temperature. After three washes with the buffer alone, the inner ears were dissected to give direct access to the organ of Corti. The samples were then dehydrated by successive washes in ethanol $(50,70,80$, 90 , and $100 \%)$, critical point dried, mounted on a stub, sputter coated with gold-palladium, and examined under a JEOL (Peabody, MA) JSM 6700F scanning microscope.

In vitro binding experiments. The cDNA fragments encoding the cytoplasmic regions of the mouse usherin (NCBI accession number NM_021408.2, amino acids 5055-5193) and Vlgr1 (NCBI accession number NM_054053, amino acids 6150-6298) and the following truncated fragments of whirlin (GenBank accession number AY739114.1, amino acids 1-260, amino acids 240-550, and amino acids 420-907) were reverse transcription (RT)-PCR amplified from mouse inner ear mRNA and cloned into pGEX-4T-1 vector for protein production in Escherichia coli BL21 cells. Glutathione S-transferase (GST) fusion proteins were purified from bacterial extracts by using glutathione-Sepharose $4 \mathrm{~B}$ beads. The cDNA encoding the long isoform of vezatin (GenBank accession number AY753561) was subcloned in pCMV-tag $3 \mathrm{~b}$ and expressed in HEK293 cells. The Myc-tagged vezatin was purified from cell extracts on an anti-Myc affinity column. Finally, the His-tagged myosin VIIa tail fragment corresponding to the C-terminal MyTH4-FERM repeat (NCBI accession number NM_000260, amino acids 1747-2215) was produced in a baculovirus system and purified on a $\mathrm{Ni}^{2+}$-agarose column.

To test for myosin VIIa tail interactions, the same amount $(4 \mu \mathrm{g})$ of GST-tagged usherin, GST-tagged Vlgr1, or GST alone was bound to glutathione-Sepharose beads $(25 \mu \mathrm{l})$ for $90 \mathrm{~min}$ at $4^{\circ} \mathrm{C}$ and then incubated with the purified myosin VIIa C-terminal fragment $(3 \mu \mathrm{g}, \sim 50 \mathrm{pmol})$, in $250 \mu \mathrm{l}$ of PBS supplemented with $50 \mathrm{~mm} \mathrm{NaCl}, 0.1 \%$ Triton X-100, and complete protease inhibitor mixture (Roche, Basel, Switzerland) for $5 \mathrm{~h}$. The beads were then washed four times with binding buffer, and bound proteins were resuspended in $50 \mu \mathrm{l}$ of $2 \times$ SDS sample buffer, separated by electrophoresis, and analyzed by Western blot using an anti-His antibody (1:1000; Qiagen, Valencia, CA). Horseradish peroxidase-conjugated goat anti-mouse antibodies (GE Healthcare) and ECL chemiluminescence system (Pierce, Rockford, IL) were used for detection. 
To test for vezatin interactions, the anti-Myc affinity beads bound to Myc-tagged vezatin $(25 \mu \mathrm{l})$ were washed intensively with cell lysis buffer (PBS complemented with $50 \mathrm{~mm} \mathrm{NaCl}, 0.5 \%$ Triton X-100, 0.1\% SDS, $5 \%$ glycerol, $0.5 \mathrm{~mm}$ DTT, $1 \mathrm{~mm}$ orthovanadate, and complete inhibitor protease mixture) and incubated with $2 \mu \mathrm{g}$ of each GST-fusion protein [whirlin fragments $(\sim 30 \mathrm{pmol})$, Vlgr1 $(\sim 50 \mathrm{pmol})$, or usherin $(\sim 50$ pmol) cytoplasmic fragments] in $250 \mu$ l of PBS supplemented with 50 $\mathrm{mm} \mathrm{NaCl}, 0.1 \%$ Triton X-100, and complete protease inhibitor mixture (Roche) overnight at $4^{\circ} \mathrm{C}$. The washing steps and Western blotting conditions were as above. Bound proteins were revealed using an anti-GST antibody (1:1000; Santa Cruz Biotechnology).

Single-cell RT-PCR. To obtain single hair cells, P6 isolated organs of Corti were collected in $100 \mu \mathrm{l}$ of PBS with 5\% trypsin at room temperature and were slowly disassembled mechanically for $4 \mathrm{~min}$. A total of 100 $\mu l$ of fetal calf serum was added for neutralization of trypsin. Isolated hair cells were then harvested with a patch pipette filled with PBS under a Nikon inverted microscope. Each hair cell was individually placed directly in $10 \mu \mathrm{l}$ of the RT mix using the SuperScript II Reverse Transcriptase kit (Invitrogen, Carlsbad, CA) according to the manufacturer's instructions, except that the RT reaction was incubated overnight at $37^{\circ} \mathrm{C}$. For each cell, we used the extracellular fluid as a negative control. A multiplex nested PCR was then performed on each hair cell or control tube using the Expand High Fidelity PCR System kit (Roche) according to the manufacturer's instructions. The first PCR was done in a total volume of $100 \mu \mathrm{l}$ (including the $10 \mu \mathrm{l}$ of the RT reaction), using specific primers (at a concentration of $1 \mu \mathrm{M}$ each) for the nine adenylyl cyclase (AC) transcripts that were tested and for two control transcripts, namely myosin VIIa, which is expressed in both OHCs and IHCs, and prestin, which is only expressed in OHCs. The PCR consisted of 20 amplification cycles $\left(40 \mathrm{~s}\right.$ at $95^{\circ} \mathrm{C}, 45 \mathrm{~s}$ at $58^{\circ} \mathrm{C}$, and $50 \mathrm{~s}$ at $72^{\circ} \mathrm{C}$ ). Primer sets were chosen on different exons to be able to discriminate between genomic DNA and cDNA (for primer sequences, see supplemental Table, available at www.jneurosci.org as supplemental material). Amplified DNA fragments had a molecular weight ranging between 300 and $500 \mathrm{bp}$. The nested PCR was performed in a $25 \mu \mathrm{l}$ mix containing $2 \mu \mathrm{l}$ of the first PCR mix and only one set of inner primers at a time through 35 cycles ( $40 \mathrm{~s}$ at $95^{\circ} \mathrm{C}, 45 \mathrm{~s}$ at $58^{\circ} \mathrm{C}$, and $50 \mathrm{~s}$ at $72^{\circ} \mathrm{C}$ ). To test whether the various cDNA fragments could be selectively amplified by the primer sets, we first performed a PCR amplification assay on entire cochlea cDNA in the same conditions. All adenylyl cyclase transcripts and control transcripts could be detected in this way.

Thirty cells were systematically collected for each experiment. For result analysis, only cells that showed the proper myosin VIIa and prestin expression profiles were computed. The number of positive cells for each adenylyl cyclase was then counted and compared statistically to the number of extracellular fluid samples showing cDNA amplification $(n=10)$ by using the $\chi^{2}$ method (with Yates correction for small samples) to check for significance $(p<0.05)$.

Electrophysiological recordings. Electrophysiological recordings from cochlear explants were performed on $\mathrm{P} 7 \mathrm{Vlgrl}^{+/+}, \mathrm{Vlgrl}^{+/-}$, and $\mathrm{Vlgrl}^{-1-}$ mice as reported previously in the rat (Kennedy et al., 2003). Briefly, the cochlear coils were finely dissected, placed under two nylon meshes, and observed under a $40 \times$ water-immersion Olympus (Tokyo, Japan) objective mounted on an Axioscope Zeiss microscope. Extracellular and dissecting solutions were identical and were composed of (in mм) $146 \mathrm{NaCl}, 5.8 \mathrm{KCl}, 1.5 \mathrm{CaCl}_{2}, 0.7 \mathrm{NaH}_{2} \mathrm{PO}_{4}, 2 \mathrm{Na}$-pyruvate, 10 glucose, and $10 \mathrm{HEPES}, \mathrm{pH} 7.4,305 \mathrm{mOsm} / \mathrm{kg}$. Intracellular solution contained (in mM) $130 \mathrm{KCl}, 10 \mathrm{NaCl}, 3.5 \mathrm{MgCl}_{2}, 1$ EGTA, $5 \mathrm{~K}_{2} \mathrm{ATP}, 0.5$ GTP, and 5 HEPES, pH 7.3, $290 \mathrm{mOsm} / \mathrm{kg}$. For dihydrostreptomycin (DHS) experiments, the extracellular solution was identical to the dissecting solution except for the $\mathrm{Ca}^{2+}$ concentration, which was $0.5 \mathrm{~mm}$ to potentiate DHS effect on the MET channels (Marcotti et al., 2005). DHS was perfused at a concentration of $0.2 \mathrm{~mm}$.

Hair cells were whole-cell voltage clamped at room temperature (20$25^{\circ} \mathrm{C}$ ) using an EPC-9 patch-clamp amplifier and the Patchmaster software (HEKA, Lambrecht, Germany). No correction was made for liquid junction potentials. Borosilicate patch pipettes (2-3 M $\Omega$ ) were approached parallel to the hair cell rows through a hole in the reticular lamina. During this approach, extracellular solution was abundantly per- fused to avoid contact between EGTA and the MET apparatus, which is sensitive to calcium chelators. Patch-clamped OHCs and IHCs were located at a distance of $\sim 20-35 \%$ the total length of the uncoiled cochlea from the apex. Series resistance was always $<10 \mathrm{M} \Omega$ and was compensated to $70 \%$. Data were sampled at $100 \mathrm{kHz}$ and filtered at $10 \mathrm{kHz}$ (eight-pole Bessel). Each transducer current presented in the figures is the average response of 10 consecutive stimulations. Stereocilia were mechanically stimulated with a glass probe fixed on a stack actuator (PA8/12; Piezosystem Jena, Jena, Germany). The tip diameter of the glass probe was $2-3 \mu \mathrm{m}$. The tilt of the probe relative to the cell apical surface was $\sim 30^{\circ}$. Voltage steps were preconditioned to avoid resonance of the actuator. To stimulate the hair bundle in the inhibitory direction, the whole preparation was rotated $180^{\circ}$, and the same glass probe was used. However, we used a fixed conventional orientation to present our results. We define as a positive deflection one that goes from the neural edge toward the stria vascularis and, as a negative deflection, one that goes in the opposite direction.

Data were analyzed using the IgorPro software (WaveMetrics, Lake Oswego, OR). $P_{\mathrm{o}}$-displacement curves were fitted with a second order Boltzmann function (Kros et al., 2002; Beurg et al., 2006). Fast adaptation time constant was evaluated by fitting a double-exponential curve onto the mechanoelectrical transduction response curve (Kennedy et al., 2003). This fit was done for the displacement corresponding to maximum hair bundle sensitivity, that is, for the response curve closest to a relative opening probability $\left(P_{\mathrm{o}}\right)$ of 0.5 . For sensitivity measurements, the mean value of the second-order Boltzmann function derivative was calculated for displacements corresponding to $P_{\mathrm{o}}$ values between 0.2 and 0.8 .

\section{Results}

\section{Vlgr1 is a component of the ankle links of the hair bundle}

The specificity of our affinity-purified antibody directed against the N-terminal extracellular region of the mouse Vlgr1 was tested by immunofluorescence imaging on whole-mount cochlear preparations from $V \lg r 1^{+/+}, \operatorname{Vlg} r 1^{+/-}$, and $\lg r 1^{-/-}$mice (Fig. $1 D, E$ and data not shown). At embryonic day 17 (E17), an intense Vlgr 1 staining was present at the base of the emerging hair bundle and on a peripheral subpopulation of microvilli located at the neural edge of the hair cell apical surface in $V \operatorname{lgr} 1^{+/+}$cochlear hair cells (Fig. $1 A, A^{\prime}$ ). At $\mathrm{P} 0-\mathrm{P} 1$, the staining extended from the very base of the stereocilia, i.e., where they anchor in the apical cell surface, to their basal first quarter (Fig. $1 B, B^{\prime}$ ). From P4 to $\mathrm{P} 9$, the labeling became restricted, forming a basal band-like pattern at the ankle-link level, above the now well distinguishable stereocilia tapering or sharpened region (Fig. $1 C, C^{\prime}, D$ ). From P12 onward, Vlgr1 was no longer detected in the cochlear hair cells (Fig. $1 F$ ). This spatiotemporal expression profile suggested that Vlgr1 is an ankle-link component. Indeed, the ankle links could not be detected in P6 Vlgr1 $1^{-1-}$ mice by scanning electron microscopy, whereas other lateral links were still present (Fig. $\left.2 A-B^{\prime}\right)$. This result confirms recently published results by McGee et al. (2006) on Vlgr1/del7TM mice that lack a functional Vlgr1. Moreover, when organs of Corti from wild-type mice were treated with either BAPTA or subtilisin, the Vlgr 1 staining disappeared from the hair bundles (Fig. 1G) (see Materials and Methods). This Vlgr1 sensitivity to BAPTA and subtilisin is reminiscent of that described for the ankle-link antigen (ALA) labeling in the chick (Goodyear and Richardson, 1999, 2003).

\section{Hair bundle abnormalities and persistence of peripheral microvilli in $\mathrm{VlgrI}^{-/-}$hair cells}

We studied the structure of the apical region of $V \operatorname{lgr} 1^{-1-}$ hair cells by scanning electron microscopy. In agreement with the anomalies reported recently in Vlgr1/del7TM mice (McGee et al., 2006), gross observations of the Vlgr1 $1^{-/-}$cochlea showed gradually in- 

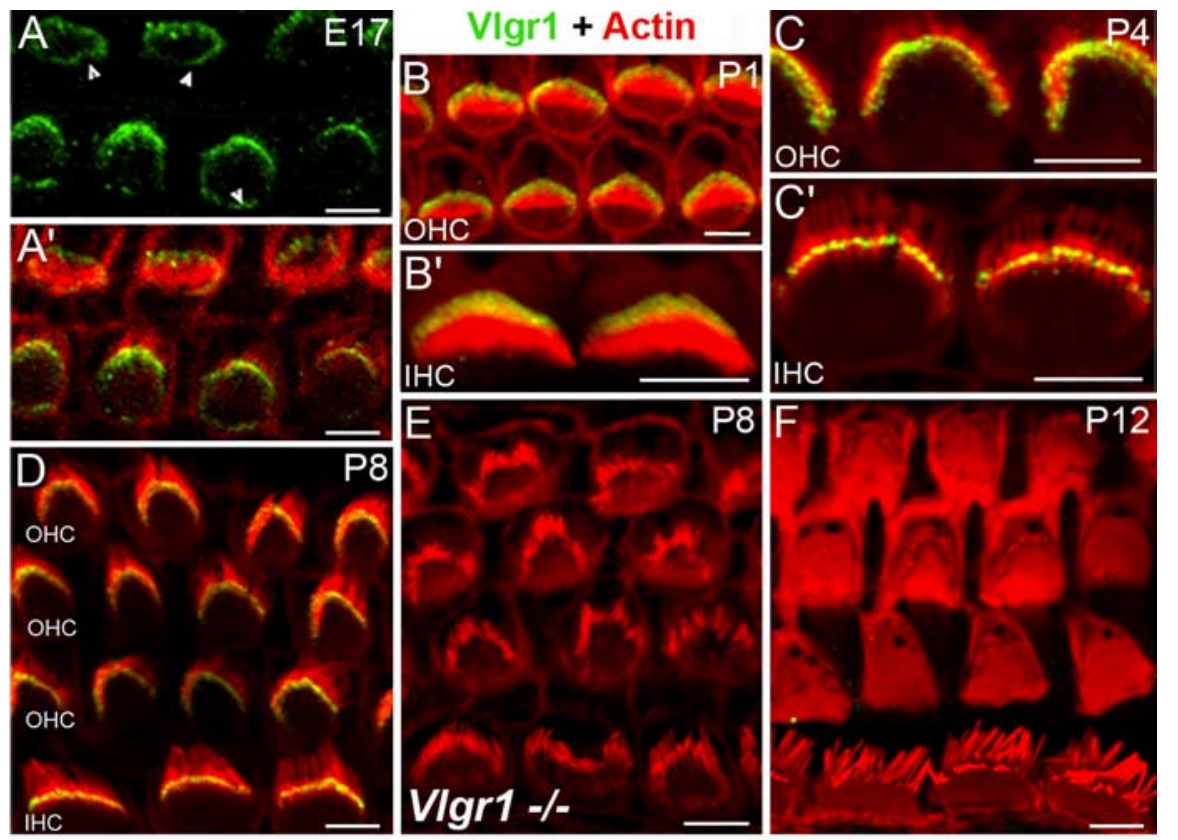

usherin was detected at the base of the hair bundles (Fig. 3A) and the immunostaining was lost after BAPTA application. However, it was still present after treatment with subtilisin, which is not in accordance with the characteristics of ALA links (Goodyear and Richardson, 1999, 2003) (supplemental Fig. 2, available at www.jneurosci.org as supplemental material). In $\mathrm{P} 6 \mathrm{Vlgrl}^{-/-}$mice, usherin could not be detected in the hair bundle (Fig. $\left.3 A^{\prime}\right)$. We conclude that Vlgr1 is required to maintain usherin at the stereocilia base and that usherin could make up interstereocilia links distinct from those carrying the ALA epitope.

Two additional proteins, namely vezatin, a putative transmembrane protein (Küssel-Andermann et al., 2000b) and whirlin, a postsynaptic density-95/Discs large/zona occludens-1 (PDZ) domaincontaining protein (Mburu et al., 2003), also have a transient band-like distribution at the base of the developing hair bundle. To study the distribution of vezatin in Vlgr ${ }^{-/-}$mice, we used a previously reported antibody (Küssel-Andermann et al., 2000b). The labeling present at the base of the stereocilia in P6 wild-type mice was colocalized with Vlgr1 (supplemental Fig. $1 A^{\prime}-D^{\prime}$, available at www. jneurosci.org as supplemental material) and could not be detected in P6 Vlgr ${ }^{-1-}$ mice (Fig. $3 B, B^{\prime}$ ). Whirlin is sequentially detected at the tip of the stereocilia rows as they start growing, and the protein is in-

creasing disorganization of the hair bundles from cochlear base to apex, starting from $\mathrm{P} 4$ at the base (Fig. $2 C-E^{\prime}$ ). However, we could observe the typical staircase pattern shaped by the three rows of stereocilia. Most OHCs exhibited U-shaped or rounded hair bundles, instead of the expected V shape, and IHCs displayed asymmetrical instead of symmetrical arch-shaped hair bundles. In addition, the peripheral subpopulation of microvilli at the neural edge side failed to regress in most IHCs and occasionally in OHCs, whereas these microvilli normally disappear before P6 in wild-type mice (Fig. $2 C^{\prime}, D^{\prime}$ ). In the mutant mice, these microvilli even underwent a stereocilia-like maturation as they organized themselves in one or two rows, conferring a circular shape to the hair bundle (Fig. $2 B^{\prime}, C^{\prime}, D^{\prime}$ ), their stereocilia base sharpened, and they displayed an increased phalloidin labeling at P11 (data not shown), thus indicating a progressive increase of their actin filament content, as observed in parallel for the genuine stereocilia. This indicates that Vlgr1, which is present in these peripheral microvilli, prevents their differentiation and is required for their regression.

Lack of Vlgr 1 results in the absence of usherin, vezatin, and whirlin at the stereocilia base

We asked whether usherin, a protein with a large extracellular region that is present at the base of the stereocilia (Adato et al., 2005b) and is colocalized with Vlgr1 (supplemental Fig. 1A-D, available at www.jneurosci.org as supplemental material), could be a component of the ankle links too. In P5 wild-type mice, volved in the control of stereocilia length (Delprat et al., 2005; Kikkawa et al., 2005; Mburu et al., 2006). In addition, whirlin is transiently present at the stereocilia base at early postnatal stages (Fig. 3C) (Delprat et al., 2005). In P6 Vlgr1 ${ }^{-1-}$ mice, the whirlin apical staining of stereocilia remained unchanged, but the protein could not be detected at their base anymore (Fig. $3 C^{\prime}$ ). Notably, whirlin was also detected at the tip, but not the base of $V \operatorname{lgr} 1^{-1-}$ supernumerary peripheral microvilli, whereas usherin and vezatin could not be detected in these structures (Fig. $\left.3 A^{\prime}, B^{\prime}, C^{\prime}\right)$.

\section{Abnormal distributions of Vlgr1, usherin, and vezatin in shaker-1 and whirler mouse mutants}

Based on the absence of harmonin, a hair bundle PDZ domaincontaining protein, from the stereocilia of myosin VIIa defective mice, we have proposed that myosin VIIa conveys harmonin to the hair bundle (Boëda et al., 2002). We thus studied the distributions of Vlgr1, usherin, and vezatin in shaker-1 4626SB mice, which lack myosin VIIa because of a nonsense mutation in the motor domain of the protein (Mburu et al., 1997). These mice are profoundly deaf and have disorganized hair bundles from the earliest stages of hair bundle development. In shaker-1 mice, Vlgr1, usherin, and vezatin were not detected in the basal region of stereocilia but formed clumps at the hair cell apical surface by immunofluorescence analysis (Fig. $4 A^{\prime}, B^{\prime}, C^{\prime}$ ). Accordingly, ankle links could not be detected in shaker-1 mutant mice (data not shown). In whirler mutant mice that lack functional whirlin 
(Mburu et al., 2003), both usherin and vezatin labelings (Fig. $4 B^{\prime \prime}, C^{\prime \prime}$ ) could not be detected either in the stereocilia or in the hair cell apical region, whereas the Vlgr1 staining was mislocated at the very base of stereocilia, below the ankle-link level (Fig. $4 A^{\prime \prime}$ ).

\section{Myosin VIIa-Vlgr1, myosin}

VIIa-usherin, and vezatin-usherin in vitro interactions

In vitro direct interactions between whirlin and the cytoplasmic regions of Vlgr1 (van Wijk et al., 2006) and usherin (Adato et al., 2005b) as well as between the myosin VIIa tail and both whirlin (Delprat et al., 2005) and vezatin (Küssel-Andermann et al., 2000b) have been established previously. However, they do not account for all concomitant delocalizations of Vlgr1, usherin, whirlin, and vezatin in $V \lg r 1^{-/-}$, shaker-1, and whirler mice. We thus asked whether vezatin could also interact with whirlin or the Vlgr 1 and usherin cytoplasmic regions. In direct in vitro binding experiments (see Materials and Methods), we were able to show that vezatin binds to the cytoplasmic region of usherin but neither to the cytoplasmic region of Vlgr 1 nor to whirlin (Fig. $5 \mathrm{~A}$ and data not shown). We then asked whether the myosin VIIa tail could also bind to Vlgr 1 or usherin and found that both Vlgr1 and usherin cytoplasmic regions bind to the myosin VIIa tail C-terminal MyTH4-FERM fragment (Fig. $5 B$ ) in a direct in vitro binding experiment.

Lack of Vlgr 1 affects the stereociliar distribution of adenylyl cyclase 6 Vlgr1 is a class B orphan GPCR (Foord et al., 2005). After ligand recognition, class $B$ GPCRs activate G-proteins containing $\mathrm{G} \alpha$ s subunits that stimulate ACs, hence cAMP production. AC1, AC4, AC6, AC7, and AC9 transcripts have been found in the mouse and rat organs of Corti by RTPCR analysis (Drescher et al., 1997; Kumagami et al., 1999). We studied the expression of AC isoforms in the mouse cochlear hair cells by single-cell RT-PCR analysis, as described previously (Adato et al., 2005b). Primers were designed to specifically amplify each of the nine mouse AC transcripts (Sunahara and Taussig, 2002) (supplemental Table, available at www. jneurosci.org as supplemental material). As shown in Figure $6 A$, only AC6 and AC9 transcripts were detected in OHCs. Both transcripts were also amplified in IHCs (data not shown). By immunofluorescence on whole-mount mature organs of Corti using antibodies recognizing both
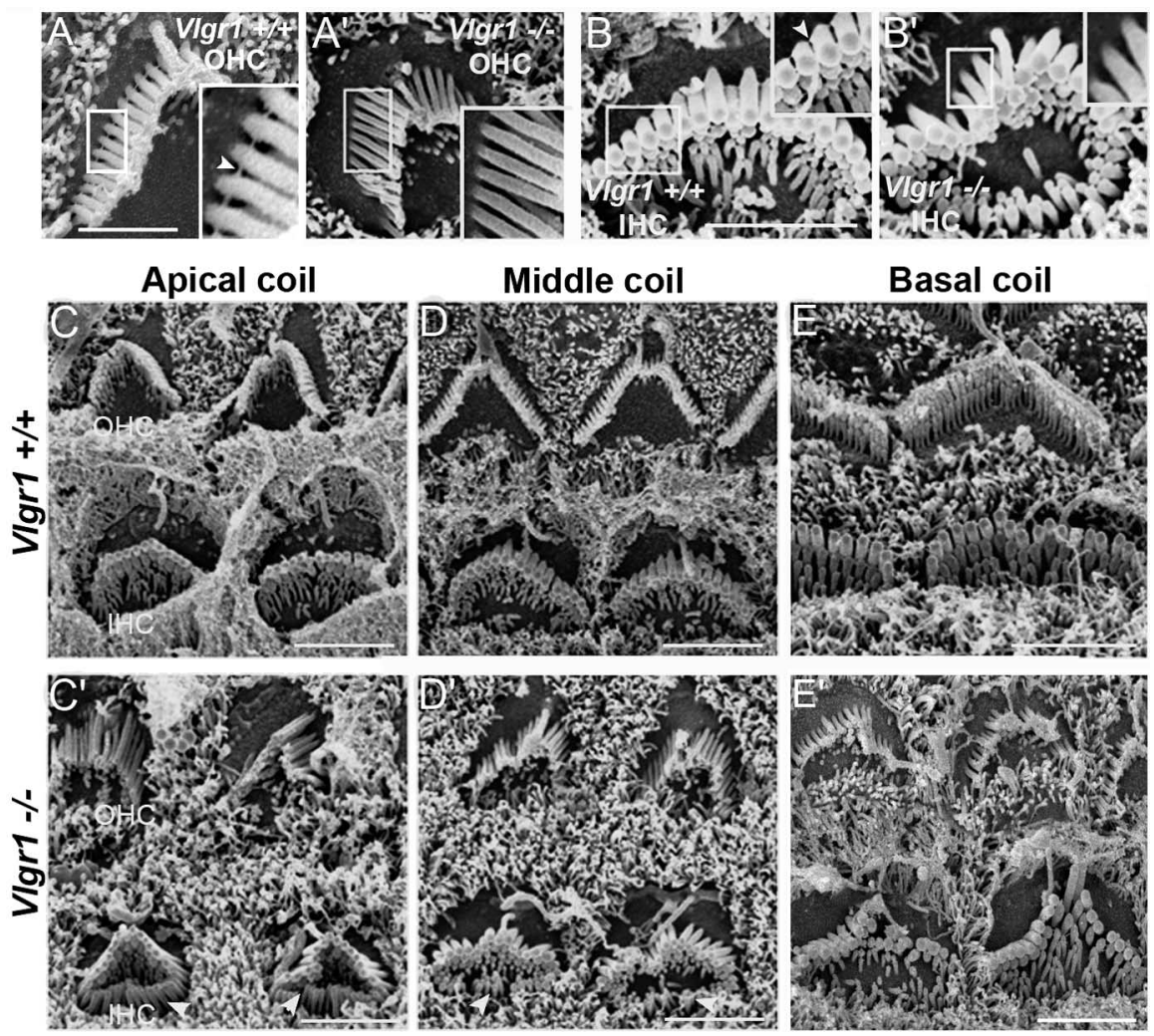

Figure 2. Morphological defects of $V I g r 1^{-1-}$ hair bundles. $A-B^{\prime}$, Scanning electron microphotographs of $\mathrm{OHC}$ and IHC hair bundles from P6 $\mathrm{VIgr}^{+/+}$and $\mathrm{Vlgr}{ }^{-/-}$mice. Insets, Enlarged views of stereocilia bases. $A, B$, Arrowheads point to the ankle links in $V I g r 1^{+/+}$hair bundles. $\boldsymbol{A}^{\prime}, \boldsymbol{B}^{\prime}$, Ankle links are absent in $V \mid g r 1^{-/-}$hair bundles. $\boldsymbol{C}-\boldsymbol{E}^{\prime}$, Scanning electron microphotographs of the surface of the organ of Corti at the apical, middle, and basal coils of cochleas from P6 VIgri ${ }^{+/+}$and $V I g r 1^{-/-}$mice. $\mathbf{C}^{\prime}, \mathbf{D}^{\prime}$, Arrowheads point to neural side supernumerary microvilli in $\mathrm{VIgr}^{-1-} \mathrm{HHCS}$. Scale bars, $4 \mu \mathrm{m}$.
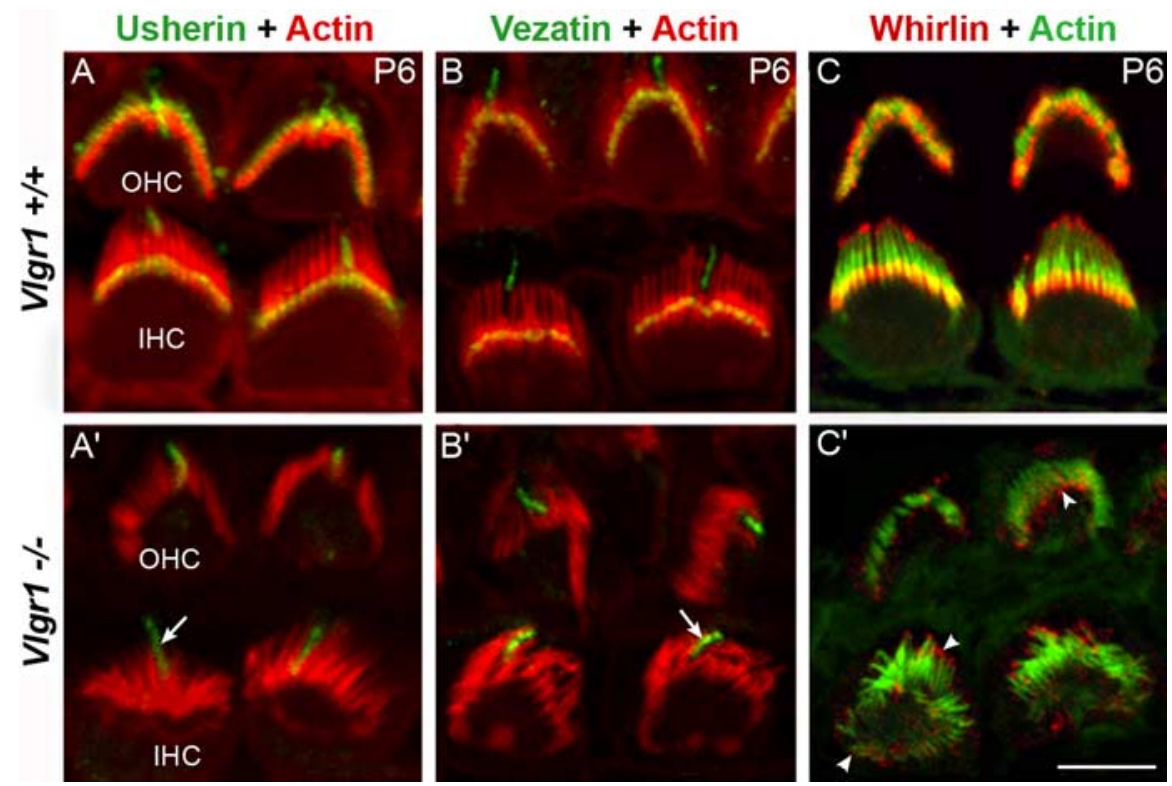

Figure 3. Hair bundle distribution of usherin, vezatin, and whirlin in $\mathrm{P} 6 \mathrm{VIgr} 1^{+/+}$and $V I g r 1^{-/-}$cochlear hair cells. $\boldsymbol{A}-\boldsymbol{B}^{\prime}$, In VIgr ${ }^{+/+}$mice, both usherin $(\boldsymbol{A})$ and vezatin $(\boldsymbol{B})$ are detected at the base of stereocilia and along the kinocilium. In $V \operatorname{lgr} 1^{-/}$ mice, usherin $\left(\boldsymbol{A}^{\prime}\right)$ and vezatin $\left(\boldsymbol{B}^{\prime}\right)$ labelings are no longer present at the base of the hair bundle but remain in the $\operatorname{kinocilium}\left(\boldsymbol{A}^{\prime}\right.$, $\boldsymbol{B}^{\prime}$, arrows) both in $\mathrm{OHCS}$ and IHCs. $\boldsymbol{C}, \boldsymbol{C}^{\prime}$, In VIgr ${ }^{+/+}$mice, whirlin is detected both at the base and apical end of stereocilia. In $\mathrm{VIgr}^{-/-}$mice, only the apical labeling can be seen $\left(\boldsymbol{C}^{\prime}\right.$, arrowheads), both in stereocilia and supernumerary neural edge microvilli. Scale bar, $4 \mu \mathrm{m}$. 

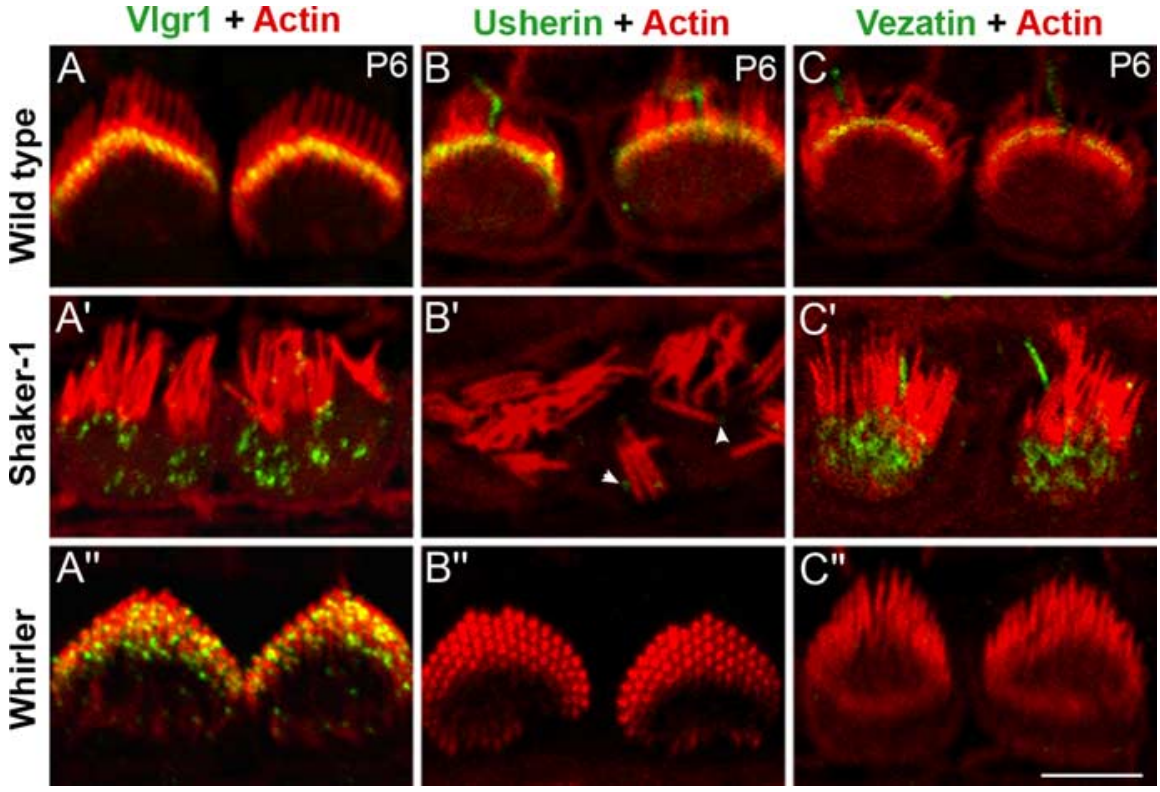

Figure 4. Distribution of VIgr1, usherin, and vezatin in the apical region of inner hair cells from P6 shaker-1 and whirler mice. In the absence of myosin VIla (shaker-1 mutant) or whirlin (whirler mutant), the proper hair bundle distributions of VIgr1, usherin, and vezatin are no longer detected. $\boldsymbol{A}-\boldsymbol{A}^{\prime \prime}$, In shaker-1 hair cells, the Vlgr1 labeling forms clumps beneath the apical cell surface $\left(\boldsymbol{A}^{\prime}\right)$, whereas in whirler hair cells, it is detected at the very base of stereocilia, i.e., below the ankle links $\left(\boldsymbol{A}^{\prime \prime}\right) . \boldsymbol{B}-\boldsymbol{B}^{\prime \prime}$, , A faint usherin staining can be seen beneath the apical cell surface in shaker-1 hair cells ( $\boldsymbol{B}^{\prime}$, arrowheads), whereas usherin cannot be detected in whirler hair cells $\left(\boldsymbol{B}^{\prime \prime}\right) . \boldsymbol{C}^{-\boldsymbol{C}^{\prime \prime}}$, The vezatin staining forms clumps beneath the apical cell surface in shaker-1 hair cells $\left(\boldsymbol{C}^{\prime}\right)$ and is not detected in whirler hair cells $\left(\mathbf{C}^{\prime \prime}\right)$. Scale bar, $4 \mu \mathrm{m}$.

A

B
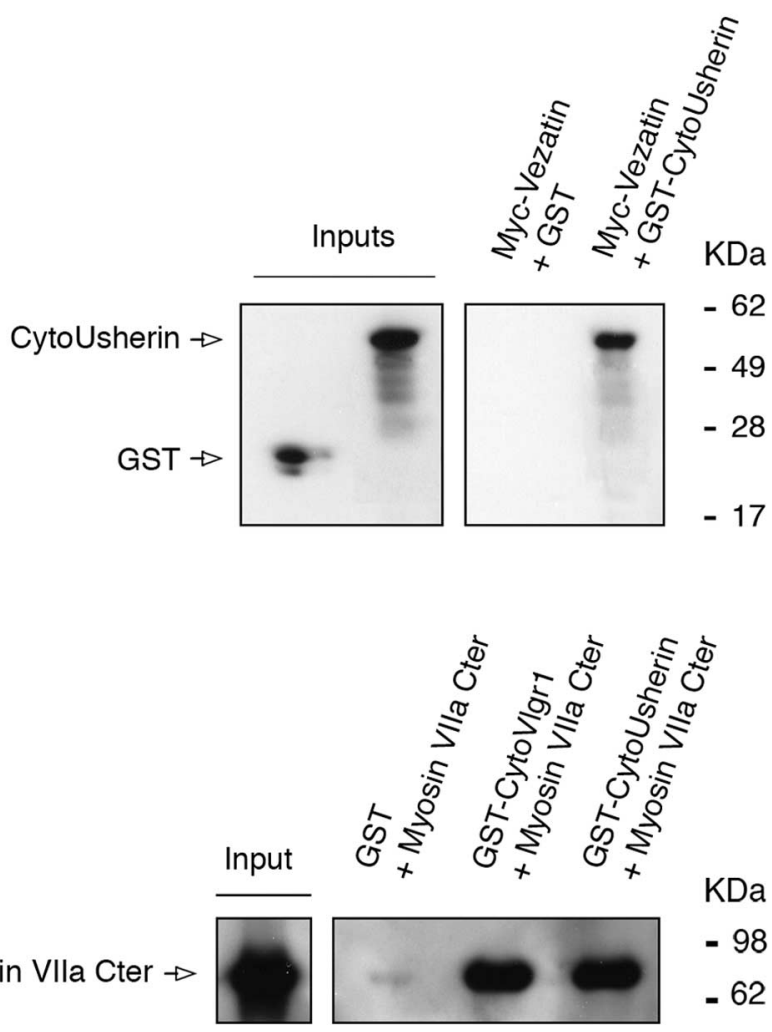

Figure 5. Myosin VIla-Vlgr1, myosinVIla-usherin, and vezatin- usherin in vitro interactions. A, Agarose beads carrying the Myc-tagged vezatin bind to a GST-fusion protein containing the cytoplasmic region of usherin (GST-CytoUsherin) but not to GST alone. $\boldsymbol{B}$, The myosin VIla C-terminal MyTH4-FERM fragment (Myosin VIla Cter) binds to GST-fusion proteins containing the cytoplasmic domain of either VIgr1 (GST-CytoVlgr1) or usherin (GST-CytoUsherin) but not to GST alone. The positions of the molecular mass markers are indicated on the right.
AC5 and AC6, we observed a clear staining at the very base of stereocilia in IHCs and OHCs. An AC9 labeling of the hair bundle was also observed, which was weaker and diffuse along stereocilia (data not shown).

We then analyzed the stereociliar distribution of AC6 during development. Between E16 and P1, AC6 labeling was present all along the stereocilia of $\mathrm{OHCs}$ but was almost undetectable in IHC hair bundles (Fig. 6 $B, C$ ). From P3 onward, the labeling of $\mathrm{OHC}$ hair bundles was restricted to their base, and AC6 became detectable at the base of IHC stereocilia (Fig. $6 D-F)$. In mature OHCs and IHCs, AC6 was still detected at the stereocilia base. In P7 Vlgr $1^{-/-}$mice, a dramatic increase in the AC6 labeling was found in $\mathrm{OHC}$ and IHC stereocilia (Fig. 6G- $H^{\prime}$ ). In addition, instead of being restricted to the stereocilia base, it extended from stereocilia base to apex in both hair cell types. In contrast, the distribution of AC9 was not modified in $\operatorname{Vlgrl}^{-1-}$ mice (data not shown).

\section{MET currents are abnormal in $V \operatorname{lgr} 1^{-/-}$ outer hair cells}

To determine whether the ankle links are involved in the MET process, we performed a comparative analysis of the response of $\operatorname{lgr} 1^{+/+}$and $V \operatorname{lgr} 1^{-/-}$hair bundles to mechanical stimulation. In P7 Vlgr1 ${ }^{+/+}$ mice, IHCs exhibited large transducer currents in response to a fast mechanical stimulus applied to the hair bundle in the excitatory (positive) direction, i.e., along the tip-link axis in the direction of the tallest stereocilia. This is the first time that MET currents are recorded in mouse IHCs using a stiff probe to stimulate the hair bundle. These currents had magnitudes comparable with those reported recently in the rat IHCs (Beurg et al., 2006). The MET channels gradually re-closed in two sequential adaptation phases, a fast one in the submillisecond range and a subsequent slow one in the 10-100 ms range (Fettiplace and Hackney, 2006). At the apical turn (20-35\%), the measured transducer currents for wild-type IHCs (Fig. 7A) had a mean saturating amplitude of $773 \pm 248 \mathrm{pA}(n=9)$ and a fast adaptation time constant of $998 \pm 367 \mu \mathrm{s}(n=8)$. In $V \lg r 1^{-1-}$ mice, all recorded IHCs (Fig. $7 A$ ) exhibited MET currents, with a mean saturating amplitude of $619 \pm 253 \mathrm{pA}(n=12)$, not significantly different from wild-type IHCs (Student's $t$ test, $p=0.18$ ). Fast adaptation was unchanged in mutant mice either with a time constant average of $898 \pm 320$ $\mu \mathrm{s}(n=10$; Student's $t$ test vs wild-type mice, $p=0.55)$. Comparing the normalized relative $P_{\mathrm{o}}$-displacement curves in $V \lg r 1^{+/+}$and $V \operatorname{lgr} 1^{-/-}$IHC hair bundles showed that neither the displacement required to open $50 \%$ of the MET channels nor the slope mean value calculated for displacements corresponding to $P_{\mathrm{o}}$ values between 0.2 and 0.8 were significantly different (Fig. $7 B^{\prime}$ ).

In contrast, Vlgr1 ${ }^{-1-}$ OHCs showed greatly impaired MET currents at P7. In $\operatorname{Vlgr}^{+/+}$mice at the apical turn (20-30\%) of the cochlea, transducer currents had a mean saturating amplitude of $853 \pm 200 \mathrm{pA}(n=5)$ and a fast adaptation time constant of $363 \pm 70 \mu \mathrm{s}(n=5)$ (Fig. $7 A)$. In $V \operatorname{lgr} 1^{-/-}$mice, all recorded $\mathrm{OHCs}$ exhibited MET currents. However, there were both a significant decrease in transducer current mean saturating ampli- 
tude and an important heterogeneity between hair cells: $220 \pm 152 \mathrm{pA}(n=12)$ in Vlgr1 ${ }^{-1-}$ OHCs at the apical turn (20-30\%; Student's $t$ test vs wild-type, $p<10^{-3}$ ). Comparing the normalized relative $P_{\mathrm{o}}$-displacement curves in $V \operatorname{lgr} 1^{+/+}$and $V \lg r 1^{-/-}$OHC hair bundles showed that the displacement required to open $50 \%$ of the MET channels and the slope mean value calculated for displacements corresponding to $P_{\mathrm{o}}$ values between 0.2 and 0.8 were significantly higher (Student's $t$ test, $\left.p<10^{-2}\right)$ and smaller $(n=$ 11; Student's $t$ test, $p=0.03$ ) in $V \lg r 1^{-1-}$ $\mathrm{OHCs}$, respectively (Fig. $7 B^{\prime}$ ). Fast adaptation was systematically present in Vlgr $1^{-1-}$ OHCs, and its time constant $(437 \pm 133 \mu \mathrm{s} ; n=8)$ was similar to that in wild-type OHCs (Student's $t$ test vs wild-type, $p=0.19$ ).

\section{Paradoxical response of the $\mathrm{Vlgr} 1^{-/-}$ hair bundles to displacements in the inhibitory direction}

Strikingly, for all Vlgr1 ${ }^{-/-}$hair bundles tested at P7, we recorded a current when they were pushed in the inhibitory or negative direction. In $V \lg r 1^{-/-}$IHCs (Fig. $8 A$ ), the threshold for MET activation in the negative direction was $182 \pm 82 \mathrm{~nm}$ $(n=12)$, and for a $1 \mu \mathrm{m}$ negative displacement, the mean recorded current was $212 \pm 162 \mathrm{pA}(n=13)$. In Vlgr1 ${ }^{-/-}$OHCs (Fig. $8 C$ ), the mean MET current threshold was $104 \pm 70 \mathrm{~nm}(n=9)$, and the mean current was $103 \pm 87 \mathrm{pA}(n=9)$ for a $1 \mu \mathrm{m}$ negative displacement. In contrast, in $V \operatorname{lgr} 1^{+/+}$hair cells (Fig. $8 \mathrm{~A}$ ), only 2 of 24 Vlgr $^{+/+}$IHCs displayed MET currents for displacements $<250 \mathrm{~nm}$ in the negative direction and the IHC mean threshold for MET activation was $856 \pm 444 \mathrm{~nm}$ (Student's $t$ test vs mutant, $p<10^{-3}$ ). For a $1 \mu \mathrm{m}$ negative displacement, the mean current value was very small: $32 \pm 52 \mathrm{pA}$ $(n=26)$ (Student's $t$ test vs mutant, $p<10^{-2}$ ). Similar results were obtained for $\lg g r 1^{+/+} \mathrm{OHC}$ hair bundles (Fig. 8C), with a mean activation threshold of $993 \pm 434 \mathrm{~nm}$ (Student's $t$ test vs mutant, $p<10^{-4}$ ) and a mean current amplitude of $7 \pm 9 \mathrm{pA}$ $(n=11)$ for a $1 \mu \mathrm{m}$ negative displacement (Student's $t$ test versus mutant, $p=0.01$ ). Both in Vlgr1 ${ }^{-1-}$ IHCs and OHCs, these currents elicited by stimulation in the negative direction were reversibly abolished by the perfusion of hair bundles with dihydrostreptomycin, an MET channel blocker (Fig. 8B,D).

\section{Cadherin 23 class A isoforms are absent from $\mathrm{Vlgr1}^{-/-}$ hair bundles}

Because loss of cohesion of the hair bundle could account for the abnormal MET current recordings in $V \operatorname{lgr} 1^{-1-}$ hair cells, we asked whether other interstereociliary links could be missing in $V \operatorname{lgr} 1^{-1-}$ mice that lack the ankle links. We focused on cadherin 23 because it has been shown to form transient lateral links during hair bundle development (Lagziel et al., 2005; Michel et al.,
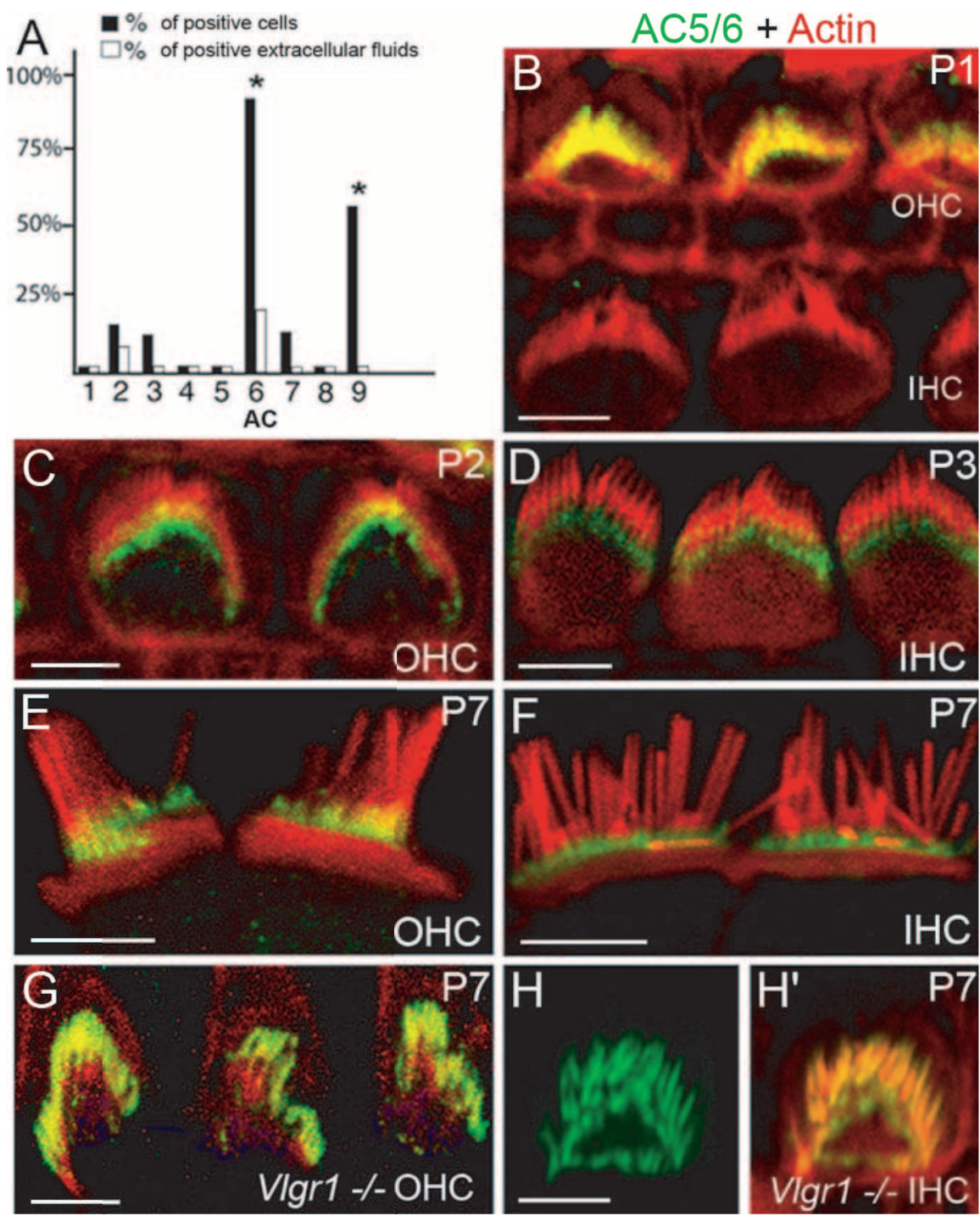

Figure 6. Adenylate cyclase 6 in $V \operatorname{lgr} 1^{+/+}$and $V \operatorname{lgr} 1^{-/-}$hair bundles. $A$, Detection of AC transcripts in P6 OHCs by using single-cell RT-PCR. Only AC6 and AC9 transcripts could be detected. $\boldsymbol{B}-\boldsymbol{F}, A C 6$ distribution in the hair bundles of middle-coil stereocilia. $\boldsymbol{C}, \boldsymbol{E}$, In P2 and P7 wild-type $\mathrm{OHCs}$, the $\mathrm{AC} 6$ labeling is restricted to the stereocilia base. $\boldsymbol{D}, \boldsymbol{F}$, In wild-type IHCs, the AC6 labeling can be detected at the stereocilia base from P3. G, $\boldsymbol{H}_{,} \boldsymbol{H}^{\prime}, \mathrm{In} \mathrm{P} 7 \mathrm{VIgr} 1^{-/-} \mathrm{OHCs}$ and IHCs, the AC6 labeling is more intense and located all along stereocilia. Scale bars, $4 \mu \mathrm{m}$.

2005). Three classes of cadherin 23 isoforms (A, B, and C) have been described in the mouse hair bundles. Class A and class $\mathrm{B}$ isoforms are transmembrane proteins that are composed of 27 and 7 extracellular cadherin repeats, respectively, whereas class $\mathrm{C}$ isoforms are cytosolic proteins. Each class consists of two isoforms, which differ by the presence or absence of a peptide encoded by exon 68 (Lagziel et al., 2005). We analyzed the distribution of cadherin 23 isoforms in P6-P7 $\lg g 1^{-/-}$mice by immunohistofluorescence. In wild-type mice, the cadherin $23 \mathrm{~N} 1$ antibody, which detects the 11th extracellular cadherin repeat (specific to class A isoforms), stains stereocilia at their tips, as reported previously (Lagziel et al., 2005) (Fig. 9B). In Vlgr1 ${ }^{-1-}$ hair bundles, the N1 labeling was present at P0 but could no longer be detected at P6 (Fig. $9 A^{\prime}, B^{\prime}$ ). In contrast, the staining observed with the cadherin 23 Ela3 antibody, which detects all cadherin 23 isoforms, had similar distributions in the wild-type and $V \operatorname{lgr} 1^{-1-}$ hair bundles both at P0 and P7 (Fig. 9C, $C^{\prime}$ ) (data not shown). At P15, the N1 and Ela3 labelings have both disap- 

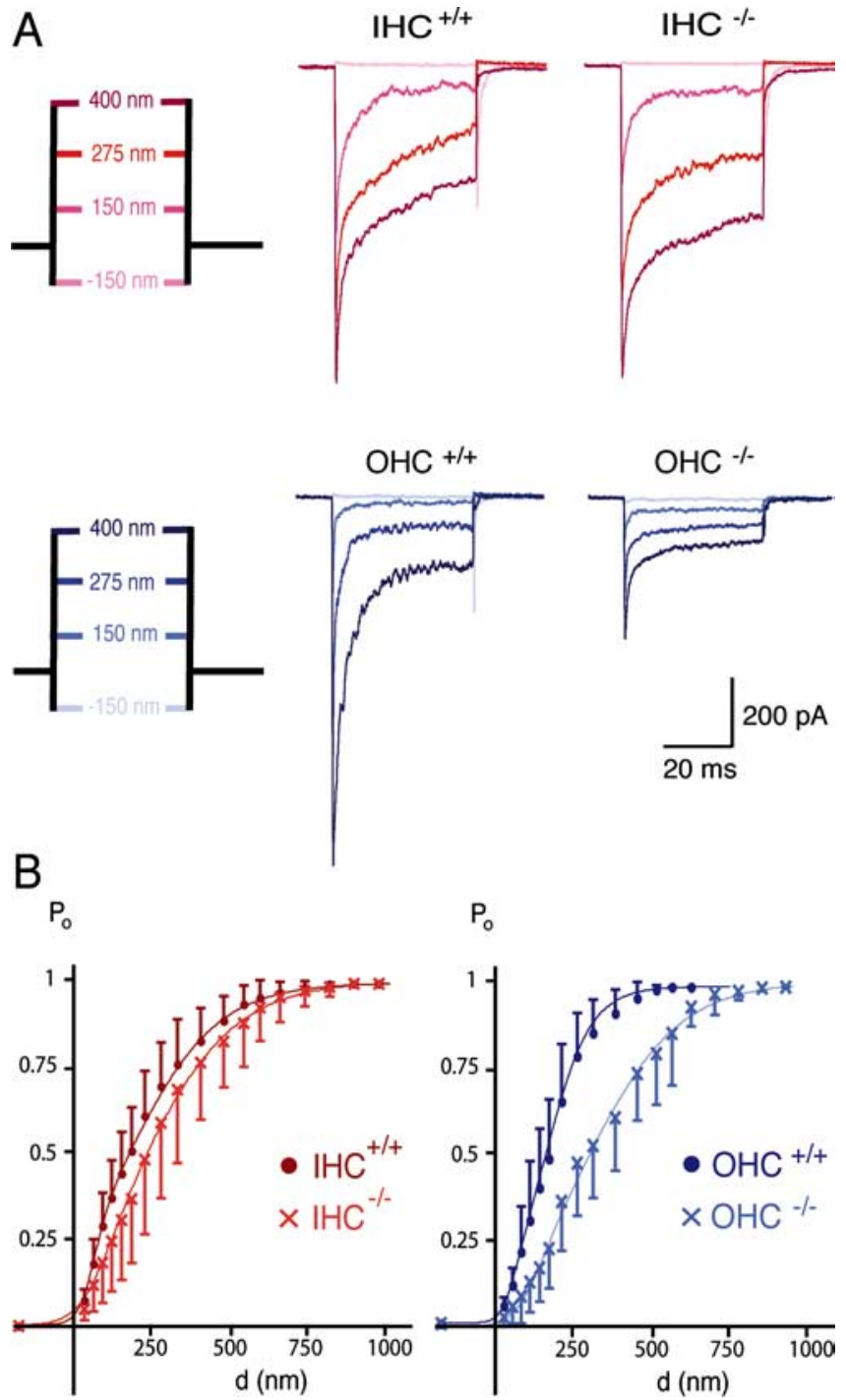

\begin{tabular}{|c|c|c|c|c|}
\hline $\mathrm{B}^{\prime}$ & $\begin{array}{c}\text { Vlgr1 } \\
(n=9)\end{array}$ & $\begin{array}{l}\text { Vlgr1 IHC } \\
(n=13)\end{array}$ & $\begin{array}{c}\text { Vlgr1 } \\
(\mathrm{n}=5)\end{array}$ & $\begin{array}{c}\text { Vlgr1 } 1+\text { OHC } \\
(n=10)\end{array}$ \\
\hline X0.5 (nm) & $182 \pm 61$ & $253 \pm 110$ & $181 \pm 57^{*}$ & $326 \pm 84$ * \\
\hline $\begin{array}{l}\text { average sensitivity } \\
\qquad(\mu \mathrm{m}-1)\end{array}$ & $2.09 \pm 0.58$ & $2.10 \pm 0.61$ & $3.68 \pm 1.27 *$ & $1.84 \pm 1^{*}$ \\
\hline
\end{tabular}

Figure 7. Mechanoelectrical transduction current recordings in the excitatory direction. $\boldsymbol{A}$, Examples of MET current recordings in IHCs (red) and $\mathrm{OHCs}$ (blue) from $\mathrm{VIgr}^{+/+}$and $\mathrm{Vlgr}^{-/-}$ P7 mice while applying different displacement steps in the excitatory direction (shown on the left) and one $150 \mathrm{~nm}$ step in the opposite direction. Cells were voltage clamped at $-80 \mathrm{mV}$. $\boldsymbol{B}$, Relative $P_{0}$-displacement curves plotted for $V \operatorname{lgr} 1^{+/+}(n=5)$ and $V \operatorname{Vgr} 1^{-/-}(n=8) \mathrm{IHCs}$ (left) and for VIgr1 ${ }^{+/+}(n=5)$ and $V I g r 1^{-/-}(n=11) 0 \mathrm{HCs}$ (right). Relative $P_{0}$-displacement curves were fit with a normalized second-order Boltzmann function: $I=1 /\left[1+\left\{\exp \left(a\left(X_{0}-\right.\right.\right.\right.$ $\left.X))\}\left\{1+\exp \left(b\left(X_{1}-X\right)\right)\right\}\right]$, where $a=0.044 \mathrm{~nm}^{-1}, b=-0.037 \mathrm{~nm}^{-1}, X_{0}=78 \mathrm{~nm}, X_{1}=$ $60.3 \mathrm{~nm}$ for VIgri ${ }^{+/+} \mathrm{IHCs}$, and $a=0.024 \mathrm{~nm}^{-1}, b=-0.017 \mathrm{~nm}^{-1}, X_{0}=123.6 \mathrm{~nm}, X_{1}=$ $86.5 \mathrm{~nm}$ for VIgr1 ${ }^{-1-}$ IHCS, and $a=0.049 \mathrm{~nm}^{-1}, b=-0.036 \mathrm{~nm}^{-1}, X_{0}=80.4 \mathrm{~nm}, X_{1}=$ $46.9 \mathrm{~nm}$ for Vlgri ${ }^{+/+}$OHCs, and $a=0.027 \mathrm{~nm}^{-1}, b=-0.020 \mathrm{~nm}^{-1}, X_{0}=166 \mathrm{~nm}, X_{1}=$ $120.4 \mathrm{~nm}$ for $V / g r 1^{-/-}$OHCs. $\boldsymbol{B}^{\prime}, X_{0.5}$ denotes average displacements required to open $50 \%$ of the MET channels and average sensitivity is the slope mean value calculated for displacements corresponding to $P_{0}$ values between 0.2 and 0.8 in $V / g r 1^{+/+}$and $V / g r 1^{-/-}$hair cells. Statistically significant differences (Student's $t$ test) are denoted by asterisks. peared in wild-type mice, whereas in P15 $V \lg r 1^{-/-}$mice, the Ela3 immunoreactivity remained as observed at P7 (data not shown). The immunolabeling of protein tyrosine phosphatase receptor Q (Ptprq), which has been proposed to form the shaft links (Goodyear et al., 2003), was not modified in the $V \operatorname{lgr} 1^{-1-}$ hair cells (supplemental Fig. 3, available at www.jneurosci.org as supplemental material).

\section{Discussion}

Based on the molecular identification of the avian ALA and immunoelectron microscopy analysis of the developing hair bundle in wild-type and Vlgr1/del7TM mutant mice, McGee et al. (2006) have shown that Vlgr1 is a component of the ankle links that connect growing stereocilia in the developing cochlear hair cells. Here, we confirmed that Vlgr1 makes up the ankle links. First, by using an antibody directed against the extracellular region of Vlgr1, we showed that the immunoreactivity of the hair bundle is strictly correlated to the transient presence of the ankle links in mouse cochlear hair cells. Second, we analyzed mutant mice carrying a different deletion of the Vlgrl gene (Yagi et al., 2005) and showed that they lack the ankle links. Third, the disruption of the ankle links that resulted from BAPTA or subtilisin treatment of wild-type hair cells was associated to the loss of Vlgr1 immunoreactivity (Yagi et al., 2007) (this study). Moreover, our results support the existence of an ankle-link molecular complex (ALC) (Fig. 10) that includes the large transmembrane protein usherin, the putative transmembrane protein vezatin, and the submembrane protein whirlin. Indeed, these molecules are colocated in the ankle-link subregion of the stereocilia and were not detected beyond P12, i.e., when the ankle-link disappearance is completed in the mouse. In addition, they were absent from $\operatorname{Vlgrl}^{-/}$stereocilia. Finally, it has been reported previously that the cytoplasmic regions of Vlgr 1 and usherin bind to whirlin in vitro (Adato et al., 2005b; van Wijk et al., 2006), and we show here that vezatin directly interacts with usherin. From the mislocation of Vlgr1 at the very base of stereocilia in the whirler mutant mice, we conclude that whirlin may determine the ankle-link accurate position at the hair bundle base. Whirlin thus could be viewed as the ALC scaffold protein, which is in agreement with the role of the long whirlin isoform (containing three PDZ domains) at this emplacement (Adato et al., 2005a,b). Notably, a genetic defect of the long whirlin isoform has been reported recently to cause USH2D (Ebermann et al., 2006). Therefore, the proteins encoded by the three USH2 genes known thus far (USH2A, USH2C, $U S H 2 D)$ would belong to the same molecular complex. A scenario of ALC formation cannot be unequivocally deduced from the molecular analysis of mutant mice defective for one or the other ALC protein. However, because we did not detect Vlgr1, usherin, whirlin, and vezatin, in the hair bundles of shaker-1 mutant mice and because all of these proteins bind to the myosin VIIa tail in vitro (Küssel-Andermann et al., 2000b; Boëda et al., 2002; Adato et al., 2005a; Delprat et al., 2005) (this study), we suggest that this actin-based motor protein conveys both transmembrane and submembrane ALC proteins, to the stereocilia. Moreover, because the PDZ domain-containing submembrane protein harmonin (Boëda et al., 2002) and the transmembrane protein protocadherin 15 (Senften et al., 2006), two stereociliary proteins, are also delocalized in shaker-1 mice and both interact directly with the myosin VIIa tail, myosin VIIa may act as a general conveyor of stereociliary proteins.

According to the GPCR subclass of Vlgr1, it is expected to activate the G-protein $\alpha$ s subunit, which in turn activates cAMPdependent signaling pathways via adenylyl cyclase and protein 
kinase $\mathrm{A}$ (PKA) activation. In this respect, A-kinase anchoring proteins (AKAPs) are believed to localize PKA to the GPCRassociated molecular complex (Malbon et al., 2004; Appert-Collin et al., 2006). Interestingly, the myosin VIIa tail has been proposed to be an AKAP because it directly interacts with the $\mathrm{R} 1 \alpha$ subunit of PKA (Küssel-Andermann et al., 2000a). Because myosin VIIa also binds to vezatin and whirlin in vitro (Küssel-Andermann et al., 2000b; Delprat et al., 2005), it is qualified to play its AKAP function in the context of the ALC. Indeed, in the mouse, myosin VIIa is mainly restricted to the base of the stereocilia between P2 and P10 both in IHCs and OHCs (V. Michel, unpublished results), whereas in the adult frog, the protein is concentrated at the level of the ankle links that, in this species, persist throughout life (Hasson et al., 1997). The restricted AC6 immunostaining just nearby the ALC in wild-type mice and its spreading out along the stereocilia in $V \lg r 1^{-/-}$mice argue in favor of a Vlgr1AC6 functional coupling. Among the nine mammalian ACs, AC6 is particular in that its activity is negatively regulated by $\mathrm{PKA}$, $\mathrm{PKC}$, and $\mathrm{Ca}^{2+}$ ions (Chiono et al., 1995; Chen et al., 1997; Beazely and Watts, 2006). The association of Vlgr1 and usherin, i.e., between a GPCR and a singlepass transmembrane protein, has been described in other GPCR complexes (Bockaert et al., 2004). Single-pass transmembrane proteins can modulate GPCR activities. This raises the attractive possibility that usherin, by its high content of FnIII repeats that are considered as reversible "mechanical shock absorbers" (ChiRosso et al., 1997), modulates Vlgr1 signaling activity during hair bundle stimulation.

Because electrophysiological recordings in $\mathrm{Vlgrl}^{-1-}$ mice showed the presence of MET currents in response to positive deflections of the hair bundle in both IHCs and OHCs, we conclude that ankle links are not necessary for the setting up of the MET apparatus and its mechanical stimulation. This result does not corroborate recent data obtained in Vlgr1/del7TM mice by McGee et al. (2006), who were only analyzing the OHCs. Indeed, almost no MET currents could be recorded in these cells at the same stage. Notably, the currents obtained by these authors in wild-type OHCs were also twofold to threefold smaller than those we recorded in $\operatorname{Vlgr} 1^{+/+}$OHCs. The site of our recordings may contribute to the difference, because they were performed $20 \%$ more basal, i.e., where OHCs have larger MET currents (Beurg et al., 2006). A striking electrophysiological feature of $V \operatorname{lgr} 1^{-/-}$IHCs and OHCs was the presence of significant MET currents for moderate mechanical stimulations of the hair bundle in the so-called inhibitory direction.
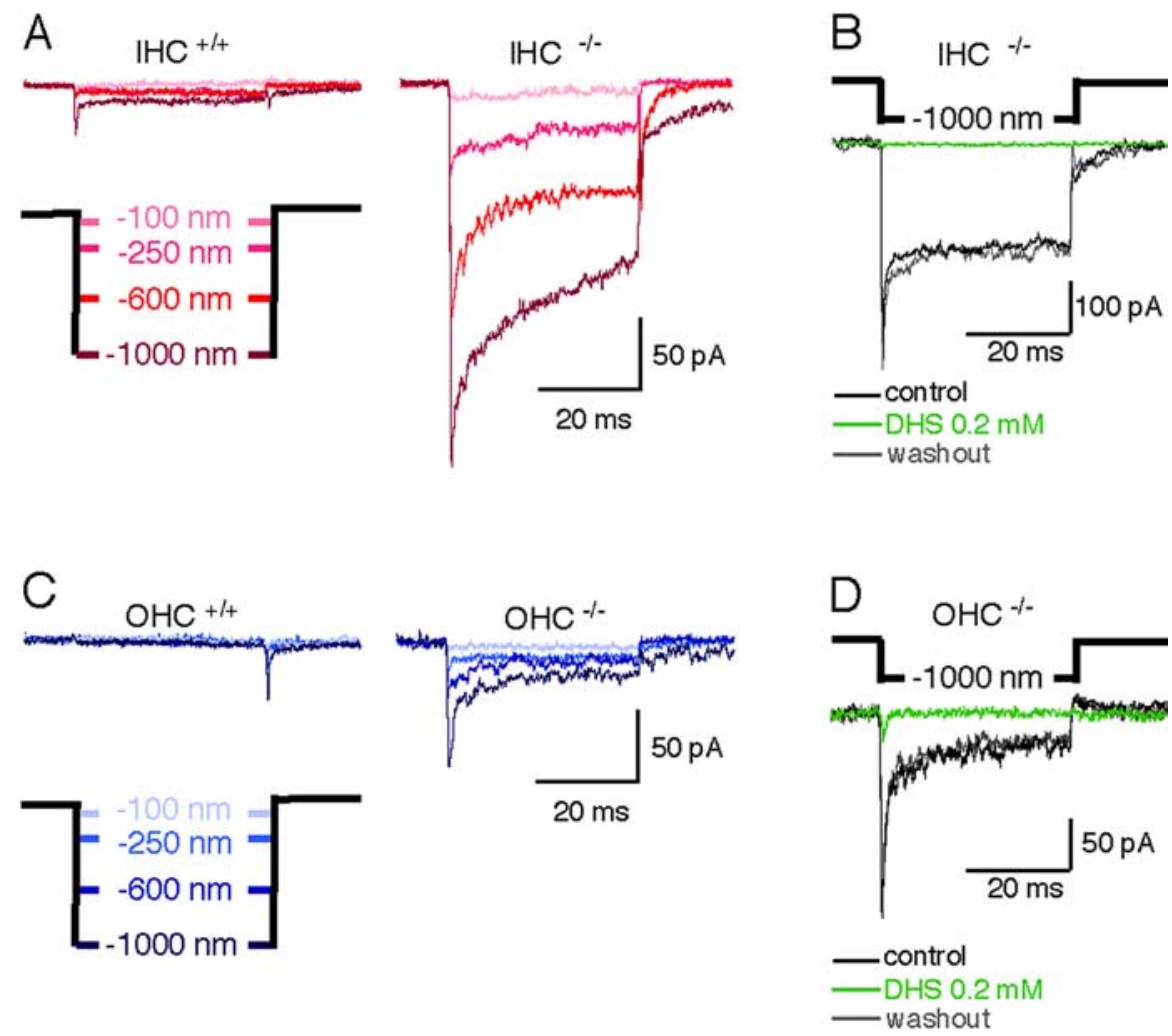

Figure 8. Mechanoelectrical transduction current recordings in the inhibitory direction. $\boldsymbol{A}, \boldsymbol{C}$, Examples of MET current recordings in $\mathrm{HCS}$ (red) and $\mathrm{OHCs}$ (blue) from Vlgr1 ${ }^{+/+}$and $\mathrm{Vlgr}^{-/-} \mathrm{P} 7$ mice while applying different displacement steps in the inhibitory direction. Cells were voltage clamped at $-80 \mathrm{mV}$. $\boldsymbol{B}, \boldsymbol{D}$, Dihydrostreptomycin (DHS) application suppresses the MET current in P7 VIgrT $^{-/-}$IHCS and OHCS.
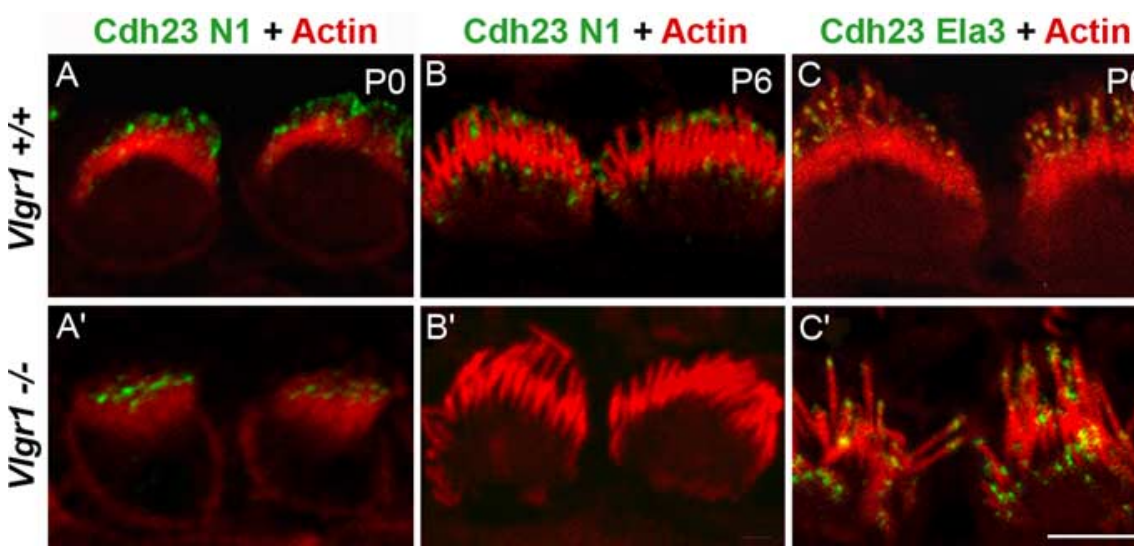

Figure 9. Hair bundle distribution of cadherin 23 in VIgr1 ${ }^{+/+}$and VIgr1 ${ }^{-/-}$inner hair cells. $A, B, C, I n P 1(A)$ and P6 (B, C) wild-type hair cells from cochlear middle coil, the $\mathrm{N} 1$ (extracellular) and Ela3 (both intracellular and extracellular) epitopes of cadherin 23 are both detected in the apical part of the stereocilia. $\boldsymbol{A}^{\prime}, \boldsymbol{B}^{\prime}, \boldsymbol{C}^{\prime}, \operatorname{In} V \operatorname{lgr} 1^{-/-}$hair cells, the N1 epitope is detected at $\mathrm{PO}\left(\boldsymbol{A}^{\prime}\right)$ but not at P6 $\left(\boldsymbol{B}^{\prime}\right)$. In contrast, the distribution of Ela3 is preserved $\left(\boldsymbol{C}^{\prime}\right)$. Scale bar, $4 \mu \mathrm{m}$.
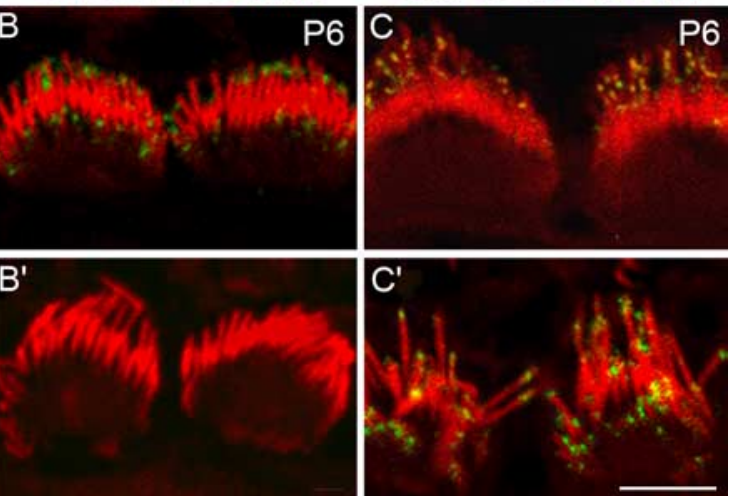

Activation of a different mechanosensitive channel is unlikely because most MET currents recorded by hair bundle stimulation in the inhibitory direction exhibited fast adaptation with time constants similar to the currents recorded when hair bundles were deflected in the excitatory direction. Moreover, this current was completely and reversibly abolished by extracellular application of dihydrostreptomycin, a permeant blocker of MET channels (Marcotti et al., 2005). The possibility that this current results from concomitant mechanical stimulation of the supernumerary microvilli also seems unlikely, because in cells 


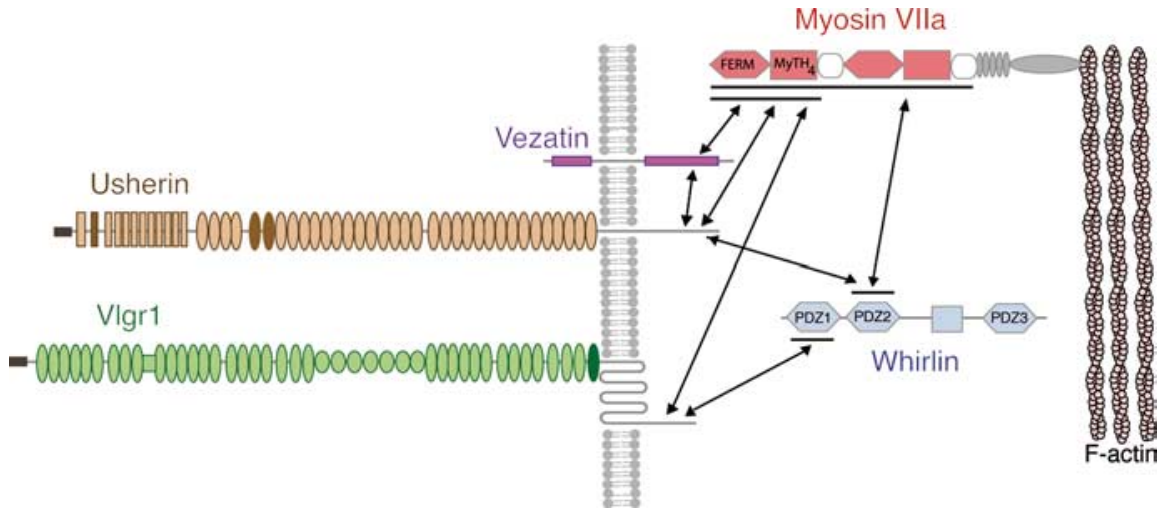

Figure 10. Schematic representation of proteins involved in the ankle-link complex. In vitro direct interactions between proteins are indicated by arrows.

that exhibited large paradoxical currents, we could not record a current when these microvilli were selectively excited with a bent probe (data not shown). Rather, we suggest that the impaired cohesion of the hair bundle in $V \operatorname{lgr} 1^{-1-}$ mutants accounts for both the decreased amplitude of MET currents in OHCs stimulated in the excitatory direction and the paradoxical currents recorded in IHCs and OHCs stimulated in the inhibitory direction. Indeed, video monitoring of the hair bundle while the probe was moved in the inhibitory direction elicited intra-row and interrow uncoordinated movements of stereocilia, many of which are likely to result in increased tip-link tension and MET channel opening probability (see supplemental videos $1-3$, available at www.

jneurosci.org as supplemental material). This abnormal coordination between stereocilia could be the direct consequence of the absence of cohesive forces mediated by the ankle links. Moreover, it could also result from the absence of some stereocilia apical links made of cadherin 23, because we did not detect the long cadherin 23 class A isoforms in P7 Vlgr1 ${ }^{-1-}$ mice. Finally, the disappearance of these cadherin isoforms in the absence of Vlgr1 suggests that the ankle links have a signaling function in hair bundle differentiation.

Both USH2C patients, who carry mutations in VLGR1, and $V \operatorname{lgr} 1^{-1-}$ mice suffer from moderate to severe hearing impairment and have severely impaired otoacoustic emissions (Weston et al., 2004; McGee et al., 2006; Yagi et al., 2007), which indicates $\mathrm{OHC}$ malfunction. Accordingly, we found that the MET currents elicited by mechanical stimulations of the hair bundle in the stimulatory direction were impaired in $\mathrm{P} 7 \mathrm{Vlgr} 1^{-1-}$ OHCs compared with wild-type, whereas these currents were not affected in Vlgr $1^{-1-}$ IHCs at the same stage. In mutant OHCs, there was a marked shift of the relative $P_{\mathrm{o}}$-displacement curve toward larger displacements and a decrease in the slope, indicating lower sensitivity of the hair bundle to mechanical stimulation. This result argues in favor of a prevailing $\mathrm{OHC}$ malfunction in USH2C. Based on the structural and functional polarity anomalies of the IHC hair bundles that we detected already at P7 in the mouse, however, a certain degree of IHC malfunction is likely to participate in the hearing loss in humans and mice.

\section{References}

Adato A, Kikkawa Y, Reiners J, Alagramam KN, Weil D, Yonekawa H, Wolfrum U, El-Amraoui A, Petit C (2005a) Interactions in the network of Usher syndrome type 1 proteins. Hum Mol Genet 14:347-356.

Adato A, Lefèvre G, Delprat B, Michel V, Michalski N, Chardenoux S, Weil D, El-Amraoui A, Petit C (2005b) Usherin, the defective protein in Usher syndrome type IIA, is likely to be a component of interstereocilia ankle links in the inner ear sensory cells. Hum Mol Genet 14:3921-3932.

Ahmed ZM, Riazuddin S, Bernstein SL, Ahmed Z, Khan S, Griffith AJ, Morell RJ, Friedman TB, Riazuddin S, Wilcox ER (2001) Mutations of the protocadherin gene $\mathrm{PCDH} 15$ cause Usher syndrome type 1F. Am J Hum Genet 69:25-34.

Alagramam KN, Yuan H, Kuehn MH, Murcia CL, Wayne S, Srisailpathy CRS, Lowry RB, Knaus R, Van Laer L, Bernier FP, Schwartz S, Lee C, Morton CC, Mullins RF, Ramesh A, Van Camp G, Hagemen GS, Woychik RP, Smith RJH (2001) Mutations in the novel protocadherin $\mathrm{PCDH} 15$ cause Usher syndrome type 1F. Hum Mol Genet 10:1709-1718.

Appert-Collin A, Baisamy L, Diviani D (2006) Regulation of $\mathrm{G}$ protein-coupled receptor signaling by A-kinase anchoring proteins. J Recept Signal Transduct Res 26:631-646.

Assad JA, Shepherd GM, Corey DP (1991) Tiplink integrity and mechanical transduction in vertebrate hair cells. Neuron 7:985-994.

Beazely MA, Watts VJ (2006) Regulatory properties of adenylate cyclases type 5 and 6: a progress report. Eur J Pharmacol 535:1-12.

Beurg M, Evans MG, Hackney CM, Fettiplace R (2006) A largeconductance calcium-selective mechanotransducer channel in mammalian cochlear hair cells. J Neurosci 26:10992-11000.

Bockaert J, Fagni L, Dumuis A, Marin P (2004) GPCR interacting proteins (GIP). Pharmacol Ther 103:203-221.

Boëda B, El-Amraoui A, Bahloul A, Goodyear R, Daviet L, Blanchard S, Perfettini I, Fath KR, Shorte S, Reiners J, Houdusse A, Legrain P, Wolfrum U, Richardson G, Petit C (2002) Myosin VIIa, harmonin, and cadherin 23, three Usher I gene products, cooperate to shape the sensory hair cell bundle. EMBO J 21:6689-6699.

Bolz H, von Brederlow B, Ramirez A, Bryda EC, Kutsche K, Nothwang HG, Seeliger M, del C-Salcedo Cabrera M, Vila MC, Molina OP, Gal A, Kubisch C (2001) Mutations of $C D H 23$, encoding a new member of the cadherin gene family, causes Usher syndrome type 1D. Nat Genet 27:108-112.

Bork JM, Peters LM, Riazuddin S, Bernstein SL, Ahmed ZM, Ness SL, Polomeno R, Ramesh A, Schloss M, Srisailpathy CRS, Wayne S, Bellman S, Desmukh D, Ahmed Z, Khan SN, Der Kaloustian VM, Li XC, Lalwani A, Riazuddin S, Bitner-Glindzicz M, Nance WE, Liu X-Z, Wistow G, Smith RJH, Griffith AJ, Wilcox ER, Friedman TB, Morell RJ (2001) Usher syndrome 1D and nonsyndromic autosomal recessive deafness DFNB12 are caused by allelic mutations of the novel cadherin-like gene $C D H 23$. Am J Hum Genet 68:26-37.

Chen Y, Harry A, Li J, Smit M, Bai X, Magnusson R, Pieroni J, Weng G, Iyengar R (1997) Adenylyl cyclase 6 is selectively regulated by protein kinase A phosphorylation in a region involved in Galphas stimulation. Proc Natl Acad Sci USA 94:14100-14104.

Chi-Rosso G, Gotwals PJ, Yang J, Ling L, Jiang K, Chao B, Baker DP, Burkly LC, Fawell SE, Koteliansky VE (1997) Fibronectin type III repeats mediate RGD-independent adhesion and signaling through activated beta 1 integrins. J Biol Chem 272:31447-31452.

Chiono M, Mahey R, Tate G, Cooper DM (1995) Capacitative Ca2+ entry exclusively inhibits cAMP synthesis in C6-2B glioma cells. Evidence that physiologically evoked $\mathrm{Ca} 2+$ entry regulates $\mathrm{Ca}(2+)$-inhibitable adenylyl cyclase in non-excitable cells. J Biol Chem 270:1149-1155.

Delprat B, Michel V, Goodyear R, Yamasaki Y, Michalski N, El-Amraoui A, Perfettini I, Legrain P, Richardson GP, Hardelin J-P, Petit C (2005) Myosin XVa and whirlin, two deafness gene products required for hair bundle growth, are located at the stereocilia tips and interact directly. Hum Mol Genet 14:401-410.

Drescher MJ, Khan KM, Beisel KW, Karadaghy AA, Hatfield JS, Kim SY, Drescher AJ, Lasak JM, Barretto RL, Shakir AH, Drescher DG (1997) Expression of adenylyl cyclase type I in cochlear inner hair cells. Brain Res Mol Brain Res 45:325-330.

Ebermann I, Scholl HP, Charbel Issa P, Becirovic E, Lamprecht J, Jurklies B, Millan JM, Aller E, Mitter D, Bolz H (2007) A novel gene for Usher syndrome type 2: mutations in the long isoform of whirlin are associated 
with retinitis pigmentosa and sensorineural hearing loss. Hum Genet 121:203-211.

El-Amraoui A, Petit C (2005) Usher I syndrome: unravelling the mechanisms that underlie the cohesion of the growing hair bundle in inner ear sensory cells. J Cell Sci 118:4593-4603.

Fettiplace R, Hackney CM (2006) The sensory and motor roles of auditory hair cells. Nat Rev Neurosci 7:19-29.

Foord SM, Bonner TI, Neubig RR, Rosser EM, Pin JP, Davenport AP, Spedding M, Harmar AJ (2005) International Union of Pharmacology. XLVI. G protein-coupled receptor list. Pharmacol Rev 57:279-288.

Goodyear RJ, Richardson GP (1999) The ankle-link antigen: an epitope sensitive to calcium chelation associated with the hair-cell surface and the calycal processes of photoreceptors. J Neurosci 19:3761-3772.

Goodyear RJ, Richardson GP (2003) A novel antigen sensitive to calcium chelation that is associated with the tip links and kinocilial links of sensory hair bundles. J Neurosci 23:4878-4887.

Goodyear RJ, Legan PK, Wright MB, Marcotti W, Oganesian A, Coats SA, Booth CJ, Kros CJ, Seifert RA, Bowen-Pope DF, Richardson GP (2003) A receptor-like inositol lipid phosphatase is required for the maturation of developing cochlear hair bundles. J Neurosci 23:9208-9219.

Goodyear RJ, Marcotti W, Kros CJ, Richardson GP (2005) Development and properties of stereociliary link types in hair cells of the mouse cochlea. J Comp Neurol 485:75-85.

Hasson T, Gillespie PG, Garcia JA, MacDonald RB, Zhao Y, Yee AG, Mooseker MS, Corey DP (1997) Unconventional myosins in inner-ear sensory epithelia. J Cell Biol 137:1287-1307.

Holme RH, Steel KP (2002) Stereocilia defects in waltzer (Cdh23), shaker1 (Myo7a) and double waltzer/shaker1 mutant mice. Hear Res 169:13-23.

Kennedy HJ, Evans MG, Crawford AC, Fettiplace R (2003) Fast adaptation of mechanoelectrical transducer channels in mammalian cochlear hair cells. Nat Neurosci 6:832-836.

Kikkawa Y, Mburu P, Morse S, Kominami R, Townsend S, Brown SD (2005) Mutant analysis reveals whirlin as a dynamic organizer in the growing hair cell stereocilium. Hum Mol Genet 14:391-400.

Kros CJ, Marcotti W, van Netten SM, Self TJ, Libby RT, Brown SD, Richardson GP, Steel KP (2002) Reduced climbing and increased slipping adaptation in cochlear hair cells of mice with Myo7a mutations. Nat Neurosci 5:41-47.

Kumagami H, Beitz E, Wild K, Zenner HP, Ruppersberg JP, Schultz JE (1999) Expression pattern of adenylyl cyclase isoforms in the inner ear of the rat by RT-PCR and immunochemical localization of calcineurin in the organ of Corti. Hear Res 132:69-75.

Küssel-Andermann P, El-Amraoui A, Safieddine S, Hardelin J-P, Nouaille S, Camonis J, Petit C (2000a) Unconventional myosin VIIA is a novel A-kinase anchoring protein. J Biol Chem 275:29654-29659.

Küssel-Andermann P, El-Amraoui A, Safieddine S, Nouaille S, Perfettini I, Lecuit M, Cossart P, Wolfrum U, Petit C (2000b) Vezatin, a novel transmembrane protein, bridges myosin VIIA to the cadherin-catenins complex. ЕMBO J 19:6020-6029.

Lagziel A, Ahmed ZM, Schultz JM, Morell RJ, Belyantseva IA, Friedman TB (2005) Spatiotemporal pattern and isoforms of cadherin 23 in wild type and waltzer mice during inner ear hair cell development. Dev Biol 280:295-306.

Malbon CC, Tao J, Wang HY (2004) AKAPs (A-kinase anchoring proteins) and molecules that compose their G-protein-coupled receptor signalling complexes. Biochem J 379:1-9.

Marcotti W, van Netten SM, Kros CJ (2005) The aminoglycoside antibiotic dihydrostreptomycin rapidly enters mouse outer hair cells through the mechano-electrical transducer channels. J Physiol (Lond) 567:505-521.

Mburu P, Liu XZ, Walsh J, Saw Jr D, Cope MJ, Gibson F, Kendrick-Jones J,
Steel KP, Brown SD (1997) Mutation analysis of the mouse myosin VIIA deafness gene. Genes Funct 1:191-203.

Mburu P, Mustapha M, Varela A, Weil D, El-Amraoui A, Holme RH, Rump A, Hardisty RE, Blanchard S, Coimbra RS, Perfettini I, Parkinson N, Mallon A-M, Glenister P, Rogers MJ, Paige AJ, Moir L, Clay J, Rosenthal A, Liu X-Z, Blanco G, Steel KP, Petit C, Brown SDM (2003) Defects in whirlin, a PDZ domain molecule involved in stereocilia elongation, cause deafness in the whirler mouse and families with mutations in DFNB31. Nat Genet 34:421-428.

Mburu P, Kikkawa Y, Townsend S, Romero R, Yonekawa H, Brown SD (2006) Whirlin complexes with p55 at the stereocilia tip during hair cell development. Proc Natl Acad Sci USA 103:10973-10978.

McGee J, Goodyear RJ, McMillan DR, Stauffer EA, Holt JR, Locke KG, Birch DG, Legan PK, White PC, Walsh EJ, Richardson GP (2006) The very large G-protein-coupled receptor VLGR1: a component of the ankle link complex required for the normal development of auditory hair bundles. J Neurosci 26:6543-6553.

McMillan DR, Kayes-Wandover KM, Richardson JA, White PC (2002) Very large $\mathrm{G}$ protein-coupled receptor-1, the largest known cell surface protein, is highly expressed in the developing central nervous system. J Biol Chem 277:785-792.

Michel V, Goodyear RJ, Weil D, Marcotti W, Perfettini I, Wolfrum U, Kros C, Richardson GP, Petit C (2005) Cadherin 23 is a component of the transient lateral links in the developing hair bundles of cochlear sensory cells. Dev Biol 280:281-294.

Pickles JO, Comis SD, Osborne MP (1984) Cross-links between stereocilia in the guinea pig organ of Corti, and their possible relation to sensory transduction. Hear Res 15:103-112.

Senften M, Schwander M, Kazmierczak P, Lillo C, Shin JB, Hasson T, Geleoc GS, Gillespie PG, Williams D, Holt JR, Muller U (2006) Physical and functional interaction between protocadherin 15 and myosin VIIa in mechanosensory hair cells. J Neurosci 26:2060-2071.

Sunahara RK, Taussig R (2002) Isoforms of mammalian adenylyl cyclase: multiplicities of signaling. Mol Interv 2:168-184.

van Wijk E, Pennings RJ, te Brinke H, Claassen A, Yntema HG, Hoefsloot LH, Cremers FP, Cremers CW, Kremer H (2004) Identification of 51 novel exons of the Usher syndrome type 2A (USH2A) gene that encode multiple conserved functional domains and that are mutated in patients with Usher syndrome type II. Am J Hum Genet 74:738-744.

van Wijk E, van der Zwaag B, Peters T, Zimmermann U, Te Brinke H, Kersten FF, Marker T, Aller E, Hoefsloot LH, Cremers CW, Cremers FP, Wolfrum U, Knipper M, Roepman R, Kremer H (2006) The DFNB31 gene product whirlin connects to the Usher protein network in the cochlea and retina by direct association with USH2A and VLGR1. Hum Mol Genet 15:751-765.

Weston MD, Luijendijk MW, Humphrey KD, Moller C, Kimberling WJ (2004) Mutations in the VLGR1 gene implicate G-protein signaling in the pathogenesis of Usher syndrome type II. Am J Hum Genet 74:357-366.

Yagi H, Takamura Y, Yoneda T, Konno D, Akagi Y, Yoshida K, Sato M (2005) Vlgr1 knockout mice show audiogenic seizure susceptibility. J Neurochem 92:191-202.

Yagi H, Tokano H, Maeda M, Takabayashi T, Nagano T, Kiyama H, Fujieda S, Kitamura K, Sato M (2007) Vlgr1 is required for proper stereocilia maturation of cochlear hair cells. Genes Cells 12:235-250.

Yap CC, Liang F, Yamazaki Y, Muto Y, Kishida H, Hayashida T, Hashikawa T, Yano R (2003) CIP98, a novel PDZ domain protein, is expressed in the central nervous system and interacts with calmodulin-dependent serine kinase. J Neurochem 85:123-134. 